University of Louisville

ThinkIR: The University of Louisville's Institutional Repository

$5-2014$

\title{
The bricks in action : women's public housing activism in Louisville, Kentucky, 1958-1970.
}

Aletia M. Robey

University of Louisville

Follow this and additional works at: https://ir.library.louisville.edu/etd

Part of the Feminist, Gender, and Sexuality Studies Commons

\section{Recommended Citation}

Robey, Aletia M., "The bricks in action : women's public housing activism in Louisville, Kentucky, 1958-1970." (2014). Electronic Theses and Dissertations. Paper 1215.

https://doi.org/10.18297/etd/1215

This Master's Thesis is brought to you for free and open access by ThinkIR: The University of Louisville's Institutional Repository. It has been accepted for inclusion in Electronic Theses and Dissertations by an authorized administrator of ThinkIR: The University of Louisville's Institutional Repository. This title appears here courtesy of the author, who has retained all other copyrights. For more information, please contact thinkir@louisville.edu. 
THE BRICKS IN ACTION:

WOMEN'S PUBLIC HOUSING ACTIVISM IN LOUISVILLE, KENTUCKY, 1958-1970

\author{
By \\ Aletia M. Robey \\ B.A., Spalding University, 2010

\begin{abstract}
A Thesis
Submitted to the Faculty of the College of Arts and Sciences of the University of Louisville in Partial Fulfillment of the Requirements

for the Degree of
\end{abstract}

Master of Arts

Department of Women's and Gender Studies

University of Louisville

May 2014 
Copyright 2014 by Aletia M. Robey

All Rights Reserved 

THE BRICKS IN ACTION:

WOMEN'S PUBLIC HOUSING ACTIVISM IN LOUISVILLE, KENTUCKY, 1958-1970

By
Aletia M. Robey
B.A., Spalding University, 2010

A thesis approved on

April 14, 2014

By the following thesis committee:

\begin{tabular}{c} 
Thesis Director \\
Dr. Cate Fosl \\
\hline Dr. Karen Christopher \\
\hline
\end{tabular}

Dr. Tracy E. K'Meyer 


\section{DEDICATION}

This thesis is dedicated to all the women who have fought for justice. 


\section{ACKNOWLEDGEMENTS}

I would like to thank my thesis directors Dr. Cate Fosl and Dr. Diane Pecknold for their guidance and patience. These two women helped me to understand the value of feminist research and inspired me to always ask questions. I would also like to thank the other committee members Dr. Karen Christopher and Dr. Tracy E. K'Meyer for their comments and assistance over the past year. I especially thank SAFY of Louisville for all the extra work they did while I conducted my research. I express special thanks to my loving and dedicated husband Paul Robey. He not only kept me motivated throughout this endeavor, he engaged with my research as if it was his own. I would also like to thank my daughter Ava Robey. She has been my drive to push forward, always. Finally, I would like to thank my parents and grandmother. The education I received from them made this whole journey possible. 


\section{ABSTRACT \\ THE BRICKS IN ACTION \\ Aletia M. Robey}

April 14, 2014

This thesis is a historical examination of women's public housing activism in Louisville, Kentucky from 1958 to 1970 . With the proclamation of the War on Poverty by President Lyndon B. Johnson in 1964, poverty stricken neighborhoods were provided with federal funding to initiate community action by public housing residents. This thesis illustrates how women living in Louisville's public housing communities organized grassroots community action groups and eventually utilized federal funds from the War on Poverty to initiate social change. Louisville activists organized by means of coalition building, increased education, and coordinated protests. Grassroots organizing in Louisville led to an established political presence of women led neighborhood groups, and improved health and safety conditions for residents of the housing projects 


\section{TABLE OF CONTENTS}

\section{PAGE}

DEDICATION .............................................................................................

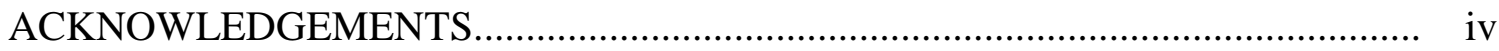

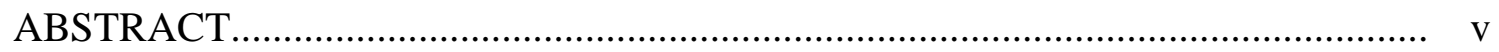

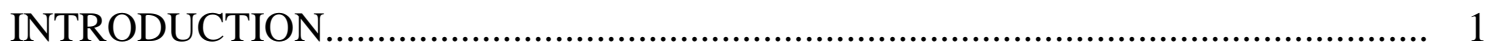

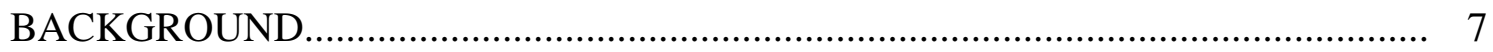

LITERATURE REVIEW ........................................................................ 13

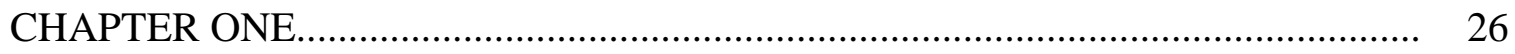

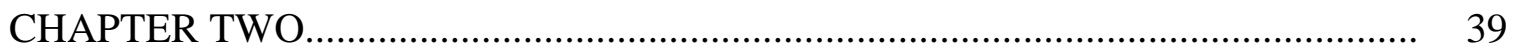

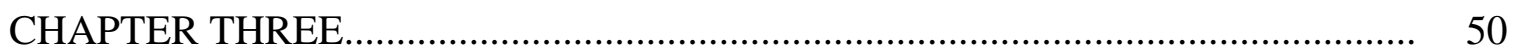

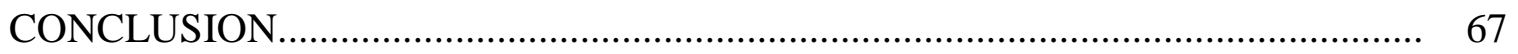

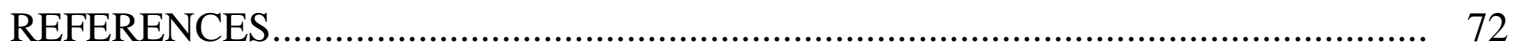

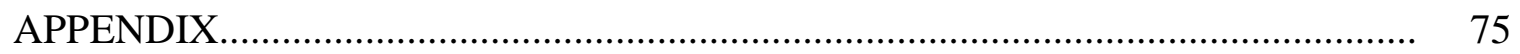

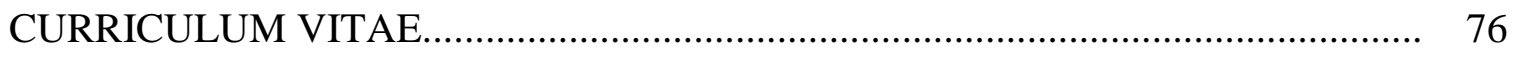




\section{INTRODUCTION}

On a spring day in Louisville in May 1966, 51-year old Vernice Hunter took to the streets of DuValle Drive and Wilson Avenue and coordinated a demonstration against deaths and injuries that had occurred in her community in the previous two years. There was not a street light at this intersection, inviting at least three deaths of fellow community members, and two others seriously injured. ${ }^{1}$ About fifty women, men, and children joined this protest and marched on the sidewalk with placards showing solidarity with their leader. Partially paralyzed, Hunter directed traffic with her whistle in one hand and her cane in the other. ${ }^{2}$ She demonstrated for at least twenty minutes before the police arrived and arrested her for obstructing traffic. ${ }^{3}$ Hunter's actions were not unsuccessful, though; she was immediately released on bond by an anonymous source, and two months later, city officials approved the installation of a traffic light. ${ }^{4}$

While it was one of the most radical demonstrations coordinated by organized neighborhood women in Louisville during the decade of the 1960's, Hunter's protest was just one of many efforts made to improve neighborhood safety within the city's majority black communities. Before and throughout the War on Poverty (WOP), women and men

\footnotetext{
1 "Traffic Stopper." The Louisville Times (Louisville), May 16, 1966.

${ }^{2}$ The Louisville Defender (Louisville), May 19, 1966, 1.

3 "Traffic Stopper." The Louisville Times (Louisville), May 16, 1966.

4 "Traffic Light Set for DuValle, Crusader Informed." Courier Journal (Louisville), July 13, 1966.
} 
in Louisville's inner-city neighborhoods met with one another in their homes, community centers, and City Hall, and collectively worked on behalf of their children and the families affected by their blighted surroundings. These women and men talked about their particular concerns and developed ideas for how to address them among themselves and with the landlords who governed their residences. They also reached out to their middle-class neighbors and the news media to convey to a larger population what was really happening in public housing communities in Louisville. The stories of how these women organized in light of the War on Poverty and the anti-poverty funds that were provided to community action agencies is the focus of this study.

This research is grounded in both historiography and in primary sources, mostly archived newspaper articles reporting and editorializing on the community action of public housing residents in Louisville throughout the WOP era. Additionally, oral histories of Louisville's prominent civil rights leaders and paid WOP community organizers, done by earlier scholars, fills in many of the details and voices that are needed to begin to develop the total story of the grassroots community action initiated by local neighborhood women. ${ }^{5}$ These sources help to answer these questions: how and around what issues did public housing residents and women living in Louisville's black

\footnotetext{
${ }^{5}$ Interview with Ruth Bryant, July 24, 1977, Oral History Center, University of Louisville Archives and Records Center, Louisville, Kentucky.; Interview with Benetha Ellis by David Cline, May 11, 2006, U-0149, in the Southern Oral History Program Collection \#4007, Southern Historical Collection, Wilson Library, University of North Carolina at Chapel Hill.; Interview with Georgia Eugene by David Cline, May 15, 2006, U-0150, in the Southern Oral History Program Collection \#4007, Southern Historical Collection, Wilson Library, University of North Carolina at Chapel Hill.; Interview with Lula Hodges by David Cline, June 2, 2006, U-0114, in the Southern Oral History Program Collection \#4007, Southern Historical Collection, Wilson Library, University of North Carolina at Chapel Hill.; Interview with Murray Walls, July 27, 1977, Oral History Center, University of Louisville Archives and Records Center, Louisville, Kentucky.
} 
community organize for social change prior to and throughout the implementation of the WOP and amid the ferment of the early 1960's Civil Rights movement around them? How did black women's neighborhood women's activism change after 1964 with the official development of the local City-County Action Agency (CAA) and the work of paid community organizers who led President Johnson's WOP? Finally, how did the implementation of the WOP in Louisville create both cross-class partnerships and divisions among black women who worked on behalf of community improvement in Louisville's west end?

This study suggests that the WOP promoted community action in public housing communities and created lasting changes in the neighborhoods of interest. An examination of pre-WOP community action illustrates both the groundwork that predated this infusion of new resources and the changes that occurred after the disbursement of anti-poverty funds. Local community organizations such as the West End Community Council (WECC) and the Southwick Improvement Club (SIC) (working out of the Southwick and Cotter/Lang Homes Public Housing Projects) were active in neighborhood improvement efforts prior to the implementation of the WOP, but the disbursement of anti-poverty funds increased their civic capacity among public housing residents. ${ }^{6}$ Moreover, the Beecher Terrace Improvement Club (BTIC) (working out of the Beecher Terrace housing community) and the Municipal Housing Commission's CityWide Residents' Council developed after the expansion of anti-poverty programs under the WOP beginning in 1964 in Louisville. Paid community organizers and newly

\footnotetext{
${ }^{6}$ K'Meyer, Tracy E. "The West End Community Council: Building Interracial Community in Louisville's West End." Ohio Valley History 7, no. 3 (2007): 6-31.
} 
available federal dollars drove these new efforts. These organizers and residents created alliances with housing and legal professionals to document and publicize the plight of the housing projects. Success came in the forms of increased police protection, community center expansions, and substantial maintenance improvements, among others. ${ }^{7}$ Like many of the female-headed grassroots community action groups of this era examined in other works by feminist scholars such as Rhonda Williams on Baltimore, Christina Greene on Durham, and Annelise Orleck on Las Vegas, Louisville women in poor and public housing communities established and sustained a political presence through strategic community organizing and active demonstrations promoted under the WOP programs.

Notwithstanding the substantial neighborhood changes that occurred as a result of neighborhood club women's community action, anti-poverty funds did prompt some minor setbacks affecting the cohesiveness of women's collective action on behalf of their community. Prior to the official implementation of the WOP in 1964 and in the years that followed, women worked collectively across class lines on behalf of physical neighborhood improvements such as the elimination of a dumping site and limited access to recreational activities in the West end of Louisville. Some public housing activists broke away from their alliance with black professional women towards the latter half of the decade by focusing on physical neighborhood improvements rather than the racial integration that was at the center of their middle-class allies' concerns. Essentially, the WOP had both positive and negative impacts on the community action of local women. These class divisions did not outweigh or eliminate the effective community action of public housing residents and their middle-class neighbors, however.

\footnotetext{
${ }^{7}$ Grieder, William. "The Poor Speak Out." The Louisville Times (Louisville), July 25, 1966.
} 
The stories of Louisville's black grassroots organizations and of women like Vernice Hunter are hardly a new phenomenon in the historiographical context of black women's neighborhood community action. My analysis of local black women's community action expands upon the growing body of literature on the black women's club movement at the localized level. Demonstrating the extent to which black women have organized against social injustices since at least the $19^{\text {th }}$ century, feminist historians Gerda Lerner and Rosalyn Terborg-Penn trace black women's neighborhood clubs to as early as 1890 . The works of these scholars have illustrated that through some of the earliest documented leadership of women such as Mary Church Terrell, who worked towards the national organization of 32 women's clubs through the National Association of Colored Women, and Ida B. Wells, who focused her organizing efforts mostly on a national anti-lynching campaign, black women have long been organizing against social and political injustices in churches, one-room school houses, and colleges to initiate social change through cross-class and interracial partnerships. ${ }^{8}$

In a piece by Lerner examining the history of the Atlanta Neighborhood Union that was organized in 1908, she reports that the group was aimed at achieving "moral, economic and social advancement of Negros," and thus served as a prototype of black women's organizing throughout the $20^{\text {th }}$ century. ${ }^{9}$ She sets forth an analysis of some of the social changes made by the Neighborhood Union that have impacted dilemmas of

\footnotetext{
8 Lerner, Gerda. "Early Community Work of Black Club Women." The Journal of Negro History 59, no. 2 (1974): 158-167.; Terborg-Penn, Rosalyn. "Teaching the History of Black Women: A Bibliographical Essay."Women's Studies Quarterly 9, no. 2 (1981): 16-17.

${ }^{9}$ Lerner, 163.
} 
poverty in poor and urban communities to this day. ${ }^{10}$ My thesis adds to the more recent research of contemporary women's studies scholars like Christina Greene and Rhonda Williams to carry forward into the 1960s this legacy of poor and black women activists first examined by Lerner and Tenborg-Penn. Current scholarship on women's activism demonstrates that value of neighborhood organizing and the necessity for federal support of community action programs, suggesting that community action programs were effective tools for social change during the War on Poverty era and thereafter.

The community developments examined in this study highlight the significant role women played in the improvements and policy developments in public housing during the WOP era. Additionally, by examining the growth and changes of these developments, this study reveals how federal funds affected grassroots organizing in Louisville's poorest communities. Using a local case study, this thesis provides new points of comparison for a growing body of urban histories of women's activism that demonstrates the common struggles shared by all women living in public housing communities, and avenues taken to alleviate such injustices. The support of WOP funds in Louisville promoted the cause of anti-poverty and the Civil Rights movement and opened new windows for political action among the city's black and public housing residents. By broadening the scope of literature on black women's activism, this study also offers a counter-argument to the conservative camp of politicians and commentators that opposes anti-poverty and community action programs. The sources examined for this

\footnotetext{
${ }^{9}$ Ibid, pp.; The Neighborhood union is still a functioning neighborhood club that continues to work on issues like housing, childcare, health care and job training.
} 
study reveal that a positive legacy of effective community action lived on in Louisville's west of town throughout the War on Poverty era and beyond it 


\section{BACKGROUND}

In January of 1964, President Lyndon B. Johnson proclaimed the official start of the War on Poverty (WOP) to address the increasing blight of poverty-stricken communities. The idea of a War on Poverty had roots in the Kennedy administration. During the 1960 primary campaign, Kennedy had toured the United States to attain an understanding of the problems facing low-income and working-class communities in rural and urban parts of the nation. ${ }^{11}$ Acting on what he'd seen, in 1962 he began antipoverty work by developing programs to combat juvenile delinquency. One of the more significant programs initiated by Kennedy's administration was Mobilization for Youth (MFY). According to historian Allen Matusow, this initiative was a "comprehensive attempt to prevent delinquency by unlocking opportunity". ${ }^{12}$ The major touch stones of this project included public service jobs for teenagers, neighborhood service centers offering welfare services, training and employment of sub-professionals in community agencies, and organizing residents to work for social change on their own behalf. ${ }^{13}$

\footnotetext{
${ }^{11}$ Matusow, Allen J. The Unraveling of America: A History of Liberalism in the 1960s. New York: Harper \& Row, 1984., 100

${ }^{12}$ Matusow, 110.

13 Ibid.
} 
Although Matusow argues that Kennedy's anti-poverty committees did little good, these programs foreshadowed the important work on poverty policy in the coming years.

After Johnson rose to the presidency he sought to continue and expand Kennedy's anti-poverty programs. The Economic Opportunity Act (EOA) was enacted in August of 1964 to give federal grants to state and local governments for subsidies and opportunities for the poor to become involved in their communities. The most influential component of the EOA lay in the development of the Community Action Program (CAP), which invited communities to establish new organizations called Community Action Agencies (CAA). As outlined by Matusow, to address the concerns of the low-income population, "CAAs were charged with mobilizing local resources for a comprehensive attack on poverty, an attack that was to have three objectives: to provide new services to the poor; to coordinate all federal, state, and local programs dealing with the poor, and to promote institutional change in the interests of the poor."14

There has been no scholarly work done to date specifically on the War on Poverty in Louisville. But the WOP is mentioned in two works on the local Civil Rights movement done by historians Tracy E K'Meyer and Luther Adams. Adams highlights location-specific nuances of community action at work in his book, Way Up North in Louisville. He argues that black migration to Louisville from both Southern and Northern cities exacerbated the looming housing crisis, establishing racially segregated but mixedclass communities that eventually developed a collective vision of their own: what he

\footnotetext{
${ }^{14}$ Ibid., 244.
} 
describes as an "urban landscape, shaped to meet blacks' needs." 15 Moreover, the masses of migrants relocating to Louisville between 1930 and 1970, some 17,000 according to Adams, assisted African Americans in gaining political power and a means to organize. ${ }^{16}$ Due to social discontent motivated by the struggle for civil rights in the WOP era, largely middle-class groups such as the West End Community Council (WECC) organized in 1963 to address the concerns of black and poor neighborhoods. ${ }^{17}$

According to K'Meyer in her book, Civil Rights in the Gateway to the South, the implementation of the CAP in Louisville's west end was largely led by the WECC, as their interest in community development aligned with that of the WOP. ${ }^{18}$ Since the local Civil Rights movement was already in full swing during the emergence of the WOP, CAP officers and CAAs were thus provided with a foundational base for organizing the poor. As addressed by both Adams and K'Meyer, in Louisville and other urban cities around the nation, both men and women crossed class and racial lines and worked together to fight Jim Crow laws and the achievement of civil rights for all. This battle made visible the reality of poor housing conditions, increasing unemployment, and subpar educational facilities for African Americans and other families living below the poverty line.

Examining interactions and cooperation between three groups of women in the west end, middle-class women, public housing residents, and working-class nonresidents, this study illustrates how these women collaborated on neighborhood projects

\footnotetext{
${ }^{15}$ Adams, Luther. Way Up North in Louisville African American Migration in the Urban South, 1930-1970. Chapel Hill: University of North Carolina Press, 2010.

16 Ibid., 89.

${ }^{17}$ K'Meyer, Tracy Elaine. Civil Rights in the Gateway to the South Louisville, Kentucky, 1945-1980. Lexington: University Press of Kentucky, 2009., 7.

18 Ibid., 161.
} 
to increase community involvement and bring about physical changes in the west end. Middle-class black and some white women focused more intently on integration and neighborhood improvement, and ultimately found success through the their partnership with the West End Community Council. Founded in 1963 through the leadership of social justice community activists Anne Braden (who was white) and Gladys Carter (who was black), WECC initially focused its attention on "welcoming black newcomers and discouraging 'white flight' in neighborhoods in the western part of the city."19 The longstanding focus of WECC, as both K'Meyer and Adams discuss, was to create and sustain integrated communities in an era characterized by white flight as African Americans moved into many western areas of Louisville for the first time. Through the seven years of its active community action (1963-1970), WECC worked on a variety of community concerns ranging from WOP programs to promoting black pride, from legal matters to arts and cultural initiatives in the West end of Louisville.

Two of the more noted black women activists who worked with the WECC were Murray Walls and Ruth Bryant. Both of these women were doctors' wives, therefore they enjoyed a particular social privilege that enabled them to lead community action efforts and initiate social change. Walls was once the tenant selection supervisor of three public housing communities and an influential member of the Human Relations Commission. She was also very active in integration campaigns and is credited with the eventual integration of the local Girls Scouts troops and the public library. Bryant, too, was extremely active with WECC and worked more closely with women living in the housing projects. She utilized her privileged position in the black community to gain a seat on

\footnotetext{
${ }^{19}$ Ibid., 10.
} 
various public service boards and promoted the value of neighborhood improvement efforts.

Largely benefitting from the community action efforts of WECC members, residents in public housing communities, like that of the Southwick and Cotter/Lang Homes projects, also did much to initiate social change in their respective communities. Located in the western part of Louisville, Southwick and Cotter/Lang homes residents formed the Southwick Improvement Club (SIC) in 1964 and focused their efforts on community improvements that would provide greater opportunity for the whole of the west end. Although less tied to the efforts of WECC, women living in the Beecher Terrace public housing community, located east of the west end and closer to downtown, also coordinated social action groups with their neighbors. With the help of federal funded Community Action Commission (CAC) community organizers, Beecher Terrace residents formed their Beecher Terrace Improvement Club (BTIC) in 1966 and focused their community action efforts on physical housing unit improvements.

After the implementation of War on Poverty programs in Louisville, the CAC was formed and provided with funds that were then released to local community groups to hire local community organizers. These organizers were assigned to work in specific public housing communities and to identify their primary concerns for neighborhood improvement. Benetha Ellis and Georgia Eugene, who were both assigned to the Southwick and Cotter/Lang Homes communities, assisted public housing residents in the development of recreational facilities in the Harris Neighborhood Center and social welfare programs at the DuValle Neighborhood Service Center. While the CAC and community action programs did in fact benefit neighborhood women and grassroots 
organizations, the program shook up alliances between some groups of women, particularly in the Southwick neighborhood. Illustrating this, Eugene, who lived in the Cotter Homes community, and Ellis who lived in private housing, reported that initially there was tension between her and public housing residents. ${ }^{20}$ Only after demonstrating commitment to the women's larger community issues did public housing residents begin to trust the paid community organizers who were assigned to their neighborhoods. In the Beecher Terrace community, Charles Vittatow, also a non-resident, mobilized community members to gain the attention of public housing officials and essentially established a working relationship between the Municipal Housing Commission (MHC) and residents. The War on Poverty initiatives taken on by CAC and others during the mid-1960's were significant in that they did, in fact, have a direct impact on total community improvement and on women's housing activism through their inter-racial and cross-class collaborative approach towards community action..

\footnotetext{
${ }^{20}$ Interview with Benetha Ellis by David Cline, May 11, 2006 , U-0149, in the Southern Oral History Program Collection \#4007, Southern Historical Collection, Wilson Library, University of North Carolina at Chapel Hill.; Interview with Georgia Eugene by David Cline, May 15, 2006, U-0150, in the Southern Oral History Program Collection \#4007, Southern Historical Collection, Wilson Library, University of North Carolina at Chapel Hill.
} 


\section{LITERATURE REVIEW}

My work is primarily historical not theoretical, yet it illustrates many elements of intersectionality introduced by key black feminist theorists such as Patricia Hills Collins and Kimberle Crenshaw. ${ }^{21}$ Collins is most noted for her work on black feminist thought, and this thesis expands upon her work by examining the ways in which black women's activism has been motived by community networks of mothers and neighborhood collations. According to Collins, "our experiences as othermothers foster a distinctive form of political activism based on negotiation and a higher degree of attention." ${ }^{22}$ This is very much representative of the community action initiated by local neighborhood women; as women living in Louisville's west end often times drew from their experiences as black women, and in the case of public housing residents, their classed status as welfare recipients to motivate their political action on behalf of the children in their communities.

This study builds on scholarship on the Louisville Civil Rights movement mentioned above and begins to fill in new insights on Louisville's experienced of the

${ }^{21}$ Collins, Patricia H. Black Feminist Thought Knowledge, Consciousness, and the Politics of Empowerment. New York: Routledge, 2000.; Cho, Sumi, Kimberle Crenshaw, and Leslie McCall. "Toward a Field of Intersectionality Studies: Theory, Applications, and Praxis." Signs 38, no. 4 (2013): 785-810. Accessed April 21, 2014.

${ }^{22}$ Collins, 160. 
WOP, contributing to several bodies of historiography as well as exemplifying key elements of black feminist theory. Recent decades have witnessed a growth in scholarly literature addressing the history of WOP grassroots organizing and the role public housing residents and middle-class women have played in initiating social change. Organizational tactics and multiracial and cross-class coalition building between women in major cities around the country have been the focus of this literature. Tamar Carrol, Christina Greene, Premilla Nadasen, and Rhonda Williams, in particular, emphasize how the welfare and the Civil Rights movement intersected and created avenues for women to understand their oppression as gendered, raced, and classed. Providing a framework for this research, the most useful themes presented in these works center around the need for maximum participation of the poor and the burgeoning welfare and Civil Rights movements that politicized the identities of welfare recipients and black public housing residents. Additionally, the methods of welfare rights activists and the supporting community organizations, of which community and resident organizers relied on to sustain their neighborhood groups, illustrates how the WOP was implemented in the nation's poorest communities and created cross-class and race coalitions in 1964 and thereafter.

Since the lesser known welfare rights movement had also been gaining steam since the early 1960's, as noted by that movement's leading historian Premilla Nadasen, it was the Civil Rights movement and CAP funds that provided the basis for welfare rights groups to "develop a collective identity and form a social movement." ${ }^{, 23}$ According to Nadasen, one of the more notable manifestations of neighborhood women's organizing

\footnotetext{
${ }^{23}$ Nadasen, Premilla. Rethinking the Welfare Rights Movement. New York: Routledge, 2012, 13.
} 
assisted by CAP funds was the National Welfare Rights Organization (NWRO). ${ }^{24}$ In her book, Rethinking the Welfare Rights Movement, Nadasen quotes a prominent welfare rights activist, Jonnie Tillman, proclaiming that, "Community action programs and agencies began to form and we began to participate. I'm sure whoever wrote those words 'maximum feasible participation of the poor,' wished they had not done that!" 25

Tillmon's statement suggests that politicians simply were not ready to deal with maximum feasible participation by the poor in addition to the political action of black professionals coming out of the Civil Rights movement. Nadasen argues that the "welfare rights protests signaled a new phase in the struggle for black equality- one addressing more directly the problem of economic deprivation," and she thereby highlights the role of economic deprivation as a unifying factor in the development of women's welfare rights and housing organizing. ${ }^{26}$ Furthermore, Nadasen suggests that the welfare rights movement should be conceptualized as a strand of activism within the black power movement and claims that the movement pushed mainstream Civil Rights leaders to take issues of poverty more seriously. ${ }^{27}$ My research on black women's public housing activism in Louisville offers new evidence of that progression.

In her study on Mobilization for Youth in New York, Carroll demonstrates that MFY was a forerunner of the WOP approach and set the framework for developing community action programs utilizing the concept of maximum feasible participation. ${ }^{28}$

\footnotetext{
24 Ibid., 24.

25 Ibid.

${ }^{26}$ Ibid., 112

${ }^{27}$ Ibid., 141

${ }^{28}$ Carroll, Tamar W. 2007. Grassroots Feminism: Direct Action Organizing and Coalition Building in New York City, 1955-1995. PhD. Diss., University of Michigan, 26-78. http://search.Proquest.com/docview/304842328?accountid=14665 (accessed December 8, 2013).
} 
She argues that the top-down strategy for social organizing on behalf of juvenile delinquents eventually shifted into a grassroots organizing effort on the part of poor minority women. Like Nadasen, Carroll argues that the intersection of civil rights and welfare politics initiated a search for common identities among women experiencing injustices as a result of their class status. So, too, her work points to the feminist activism that was apparent in women's grassroots community action groups as a result of their status as black women receiving welfare benefits. ${ }^{29}$

The organizers of the welfare rights movement, mostly poor black women, experienced unique challenges to their community action due to their low class status as welfare recipients. As noted by sociologist Jill Quadagno in her book The Color of Welfare, embedded racism and sexism within the welfare system served as a means to keep women in a low social standing. Quadagno contends that "The long-term legacy of coupling social policy to racial issues had diminished America's ability to stem the decline of the inner cities and to protect the family, whether it consists of two working parents or of single mothers. ${ }^{30}$ Additionally, as noted by other scholars mentioned in this thesis, women receiving government assistance were assumed to be lazy, immoral, and undeserving of government assistance. Black feminist theorist Dorothy Roberts, writing on the misguided ideology of the "welfare queen," contends that "the American public associates welfare payments to single mothers... who deliberately become pregnant in order to increase the amount of her monthly check." ${ }^{31}$ Confirming this perspective,

\footnotetext{
${ }^{29}$ Carroll, 200-205.

${ }^{30}$ Quadagno, Jill S. The Color of Welfare: How Racism Undermined the War on Poverty. New York: Oxford University Press, 1994, 14.

${ }^{31}$ Roberts, Dorothy E. Killing the Black Body: Race, Reproduction, and the Meaning of Liberty. New York: Pantheon Books, 1997., 111.
} 
historian Rhonda Williams writes “...black women who sought low-income assistance became 'repositories of 'as well as symbols 'for all that could go wrong in American society", 32 These assumptions led many city officials and welfare service providers to treat public housing residents as less than human. Women in these communities were often subject to random visits from case workers, or denied benefits as a result of male companionship among other things.

As noted by historian Anne M. Valk, "recipients of public assistance were conscious of and angered by the ways the welfare system acted as a form of social control. Recipient-activists not only demanded increased funds, but also insisted that selfdetermination and participation in shaping politics would permit them to be better mothers. ${ }^{, 33}$ Expanding upon the literature documenting the anti-poverty movement, this study highlights that these same demands were also important to Louisville welfare activists. Neighborhood women demanded a reassessment of the policy banning women with multiple illegitimate children from the housing projects, and insisted that the housing commission take seriously the increase in attacks on women in their communities.

In her study of women in the black freedom movement in Durham, North Carolina, Greene finds that "impoverished African American women often deployed distinctive modes of resistance, at times transforming 'social problems' (such as femaleheaded households or neighborhood juke joints) into social assets and foundations for

\footnotetext{
${ }^{32}$ Williams, Rhonda Y., The Politics of Public Housing Black Women's Struggles against Urban Inequality. New York: Oxford University Press, 2004, 128.

${ }^{33}$ Valk, Anne M. "'Mother Power": The Movement for Welfare Rights in Washington, D.C., 1966-1972." Journal of Women's History 11, no. 4 (2000): 35.
} 
wider community protest" before WOP funds were released. ${ }^{34}$ In Durham, when resident councils were formed in 1964 by city officials in an attempt to shape the maximum feasible participation of the poor, Civil Rights and welfare activists had already proven their influence as a political necessity in the bureaucratic methods of decision making. ${ }^{35}$ Greene says, "Poor blacks wasted no time in clamoring for expanded services and, more crucially for an active voice in shaping the policies that directed their lives. ${ }^{, 36}$ In Durham and other cities around the nation, CAP eventually created jobs and hired some of the most active organizers. Consequently, in the eyes of mayors, city officials, and middleclass skeptics, these community organizing opportunities provided black and poor Americans a legitimized space for civic engagement. While the Civil Rights movement seems to be of primary importance as a progenitor of the community action in Durham, Greene identifies similar recruitment and political strategies as were apparent in the welfare rights movement examined by Nadasen, and Williams. Poor African American women and mothers formed neighborhood groups to rally against the constant increase in rent, poor living conditions, and unjust practices of their landlords. ${ }^{37}$

When WOP funds became available in Durham, Operation Breakthrough was formed to increase civic capacity of these women's organizations. The employment of the poor in government programs, much like the practices I discuss at the DuValle Neighborhood Service Center in Louisville, challenged the notion that welfare recipients were immoral or lazy. This component of CAP programs was significant in that it laid the

\footnotetext{
${ }^{34}$ Greene, Christina. Our Separate Ways: Women and the Black Freedom Movement in Durham, North Carolina. Chapel Hill: University of North Carolina Press, 2005, 109.

${ }^{35}$ Green, 110.

${ }^{36}$ Ibid.

${ }^{37} \mathrm{lbid}, 111$.
} 
foundation for a new understanding of what contributes to poverty and more effective ways to combat it. With public housing residents having a voice in the development and disbursement of welfare services, men and women built coalitions across both class and racial lines and initiated social change within their respective communities. The case study of Durham is similar to the work of local activists presented in this thesis in that it demonstrates the complexities of community action when crossing class, gender, and racial boundaries in a southern city. The similarities that exist between Louisville and Durham regarding the impact of the Civil Rights movement on women's organizing efforts in blighted communities during the WOP era demonstrate the extent to which public housing residents were motivated to make change on behalf of the total black community.

In The Politics of Public Housing, Rhonda Williams gives considerable attention to other WOP nuances and organizing strategies that influenced community action as it relates to housing activism. In her case study on the decaying project housing communities in Baltimore before and throughout the 1960's, Williams finds that "the federal government and local officials did not desire a radical shift in power, competition, or even a critique of the way the government operated; after all, they did not believe the problem lay with the government or the economy, but with the people."38 Although she notes that middle-class partnerships and CAP policies were, indeed, essential to women's public housing activism, the power wielded by middle-class professional men hindered social progress within the anti-poverty movement in Baltimore and other cities across the nation.

\footnotetext{
${ }^{38}$ Williams, 165.
} 
In contrast to the more conservative Matusow- who argues that funds from the WOP created an imbalance in political structures, causing discontent among participating citizens and primarily resulting in a waste of money and time- Williams, on the other hand, argues that the early organizing by welfare rights activists, supported by WOP funds, actually aided in the development of tenant rights activism in Baltimore. ${ }^{39}$ Tenant activists participated in city council and judiciary meetings, and literature and material they developed alongside the NWRO contributed to the strategies of various community action groups around the nation. ${ }^{40}$ According to Williams, tenant activists in Baltimore effectively utilized the CAP funds from the WOP to promote civic engagement by public housing residents and increased the capacity to make political social reform within housing institutions.

Baltimore's public housing communities had some of the worst living conditions in the nation, and, like Louisville's grassroots activists, women in these communities drew from the welfare and Civil Rights movements to create and legitimatize their political presence. My study illustrates that the activism of the Southwick Improvement Club (SIC) and the federally funded Beecher Terrace Improvement Club (BTIC), among others, are comparable to the community action of women living in Baltimore's tenant housing organizations, and also of black power activists in Durham, as its women leaders drew from the Civil Rights movement and crossed class lines when developing partnerships with neighborhood clubs. Additionally, both middle-class women and poor

\footnotetext{
${ }^{39}$ Williams, 159.

40 "Tenants' Rights Book Is Popular With Landlords." Courier Journal (Louisville), June 18, 1970.
} 
women of color in the Louisville story utilized CAP funds and the experience of paid CAC organizers to inform, expand, and implement their organizing strategies.

Further exploring the effects of the WOP after its 1964 implementation, feminist scholar Annelise Orleck offers a bottom-up analysis of the WOP and the implementation of CAP programs in her book, The War on Poverty: A New Grassroots History, 19641980. She calls for a change in the way we understand welfare activism, arguing that to fully understand the social change that occurred as a result of the WOP; we must conceptualize WOP activism from a bottom-up perspective rather than understanding poverty as a concern of the middle-class aimed at the poor. ${ }^{41}$ She contends, as do others mentioned here, that social change occurred as a result of poor women's activism motivated by their lived experiences and status as public housing residents. Orleck criticizes Matusow and sociologist Jill Quadagno for placing too much emphasis on the top-down effects of conservative politics and institutionalized racism, thus sidelining the many successes of the grassroots organizing that came from WOP anti-poverty initiatives. ${ }^{42}$ Focusing attention on the many successes of women's housing activism in Louisville's public housing communities, this study builds on the arguments put forth by Orleck. I employ this same bottom-up approach of conceptualizing the WOP in Louisville, thus illustrating the power of neighborhood women and their grassroots community action efforts prior to and throughout the WOP.

Like the many major cities examined by the scholars mentioned above, Louisville, too, has a complicated history of public housing that was highly influenced by

\footnotetext{
${ }^{41}$ Orleck, Annelise, and Lisa Gayle Hazirjian. The War on Poverty A New Grassroots History, 1964-1980. Athens: University of Georgia Press, 2011, 4.

${ }^{42}$ Orleck, 451.
} 
racialized housing policies and unethical maintenance practices. Works by K'Meyer, Adams, and others reveal that black women's grassroots organizations were motivated by these factors prior to the implementation of the WOP. This study unpacks those findings, showing that as early as 1958, black women living in Louisville's public housing communities were organizing in their communities to address their neighborhoods' concerns. Neighborhood groups such as the SIC, developed by Southwick and Cotter Homes residents, initiated this organizing in public forums and worked to address rat infestation, poor police protection, and minimal recreational facilities for children. By the time WOP funds became available in 1965 to already established neighborhood groups such as WECC, women living in public housing had already situated themselves as necessary constituents in the plan to promote maximum feasible participation in Louisville's implementation of the federally funded CAA. The sustainability of their community action was promoted by alliance building with WECC and thus demonstrates the value of anti-poverty efforts.

Attention paid to local public housing residents' organizing efforts extends scholarship in several ways. While existing studies have begun to address some of the complexity of poor women's grassroots organizing, they have generally examined these issues in the context of large northern and border cities as in the case of Baltimore's tenant rights movement and New York's welfare rights movement. ${ }^{43}$ Emphasis on the social environment of southern cities like Durham and Louisville is needed because, as Nadasen contends, the "Black movement in the South, even prior to 1965, had many different strands. Most of those participating in and affected by the southern movement

\footnotetext{
${ }^{43}$ Examined by both Williams and Nadasen.
} 
were poor." ${ }^{44}$ Examining the nuances of social movements in southern cities provides new insight as to how poor and black citizens navigated the tense race relations outlined by Adams and Greene, as well as in K'Meyer's work on WECC and civil rights activism.

Similar to the case of the Durham story, Louisville is a smaller southern city in a rural conservative state, with large African American communities (albeit more concentrated in urban areas in the case of Kentucky) and the resulting tense race relations. I suggest that the story of Louisville is not unlike the one of Durham wherein middle-class and poor black women worked against racism and classism through the collective action of women-led community groups in public housing communities. An analysis and documentation of neighborhood women activists and the middle-class liberals that supported them sheds light on Louisville's place in the national narrative of the War on Poverty.

Chapter One begins by establishing a context regarding the social and political environment in Louisville from the mid 1950's to the late 1960's. Illustrating the historical landscape of inequality within which residents organized to implement social change, this chapter explores the fierce injustices neighborhood women began to organize against. Examining the disproportionate amount of safety concerns that were outright ignored in poor neighborhoods of African American communities, this chapter sets the foundation for understanding the particular social ills experienced by poor and black communities in Louisville before and throughout the War on Poverty. Additionally, this chapter illustrates the extent to which public housing residents were dependent upon the

\footnotetext{
${ }^{44}$ Nadasen, 142.
} 
community action efforts of their neighbors in the west end to expand their organizing efforts.

Chapter Two showcases the major social and political leaders pre-WOP in public housing communities and middle-class black residential neighborhoods. Among them are Murray Walls, Ruth Bryant, Vernice Hunter, and members of the Southwick Improvement Club. Both Walls and Bryant earned much political clout throughout their careers in civic community action and local politics throughout the 1960's and 1970's. Hunter, whose activism is examined most thoroughly in this second chapter, was a lowerincome community crusader who lived in the Cotter Homes project. An analysis of her activism and that of other public housing residents during this period establishes a framework for comparison when surveying the implementation of WOP programs in public housing communities that are examined in Chapter Three. In addition to following the successes of pre-WOP organizers, Chapter Three outlines the development of new CAC organized neighborhoods groups guided by paid community organizers such as Benetha Ellis, Charles Vitttatow, and Georgia Eugene, and the subsequent outcomes of the anti-poverty programs in the black public housing communities they served. Moreover, Chapter Three investigates the extent to which CAC either benefited the social action of women public housing activists or divided them against middle-class allies.

In the words of Orleck, "That successes did not happen in every locale where War on Poverty funds spurred community action is not surprising." ${ }^{45}$ But in the Louisville story, there were substantial achievements made by neighborhood women, and some of them still stand today, such as the ongoing occurrences of residents' councils in many of

\footnotetext{
${ }^{45}$ Orleck, 23.
} 
the local housing projects. ${ }^{46}$ The inclusion of Louisville's story in the national narrative of the War on Poverty extends our understanding of this important period, and this case study offers a rethinking of the anti-poverty movement that showcases the many successes of Louisville's War on Poverty leaders and profiles both its strengths and weaknesses and the challenges of working across class differences for social change.

\footnotetext{
${ }^{46}$ Although the Park DuValle that stands today was actually expanded by Hope IV initiatives in 1995, the building and many of the programs available were established before and throughout the War on Poverty. 


\section{CHAPTER ONE}

Throughout the late 1950's, and stretching through the 1970's, African American women living in Louisville from all class backgrounds were politically active in their neighborhoods and organized for social change on behalf of the total community. While not always strictly low-income, black women living in Louisville's public housing communities were often poorly educated, underemployed and simultaneously overworked; yet they managed to come together collectively to get to the root of the neighborhoods' poor living conditions. This chapter explores the particular social ills experienced by these black and poor Louisvillians during the WOP era, and their dependence upon middle-class allies to initiate social change. Segregation, racism, and the lack of economic opportunity fueled many of grassroots leaders' motivation for community action, and working across class lines, black Louisvillians became dependent upon one another in pursuing their goals of total community improvement.

Sitting at the northern border of the state, Louisville, Kentucky has been a migration point for many African Americans, whether they were returning closer to their 
original southern homes, or moving towards the North in search of more opportunity. ${ }^{47}$ Combined with institutionalized racism at work in local bureaucracies, this influx of African Americans in the city and the process of racialized housing segregation created dense and economically diverse African American communities placed in a checkered pattern adjacent to white neighborhoods throughout the downtown and western parts of the city. ${ }^{48}$ The Park DuValle, Russell, California, Shawnee, and later the Smoketown neighborhoods housed the growing African American communities, and these neighborhoods were home to various blighted housing areas and industrial plants that eventually polluted the area. Limited housing options confined black communities to this part of town and the resulting effect of "white flight" further segregated these communities. $^{49}$

In the 1961 Report of the Mayor's Committee on Human Rights, partially written by middle-class community activist Murray Walls, the members of the non-partisan and interracial committee noted a loss of "community self-respect" as a result of the previous years' demonstrations against segregation, which had resulted in financial loss to the community. ${ }^{50}$ Beginning in 1956, Louisville schools and housing communities had begun the process of desegregating public facilities to ease racial tensions; and the city of Louisville won positive national headlines for its ease of racial integration in public schools. But the Report identified that the city's history was not without complication in

\footnotetext{
${ }^{47}$ Adams, Luther. Way Up North in Louisville African American Migration in the Urban South, 1930-1970. Chapel Hill: University of North Carolina Press, 2010.

${ }^{48}$ K'Meyer, Tracy E. Civil Rights in the Gateway to the South Louisville, Kentucky, 1945-1980. Lexington: University Press of Kentucky, 2009, 200; K'Meyer, 5-6; Adams, 160.

${ }^{49}$ Committee On Human Rights. Report of the Mayor's Committee On Human Rights. Walls Papers: University of Louisville Archives, 1961. Accessed September 12, 2012.

50 lbid.
} 
matters of housing. ${ }^{51}$ The Report stated that while school desegregation was implemented peacefully, housing integration remained at an embarrassingly low rate as of 1961. Examining the status of public housing communities, the Committee reported that only $1 \%$ of the projects were integrated and they were receiving little attention from city officials in promoting the causes of neighborhood improvement and integration in the projects. $^{52}$

Fueled by the continued segregation in public housing communities and a general devaluing of the black families that lived in the projects illustrated in this study, the concerns over physical neighborhood improvements were more pronounced for the public housing residents as compared to those of middle-class and professional black men and women living in other parts of Louisville's west end. While neighborhood dumping sites and few recreational facilities were a plague to the total community, the issue of damaged door locks, few street lights, and broken windows posed direct threats to the physical safety of families living in public housing. So, too, did the dumping sites that were located directly across from the Southwick housing projects, a source of potential contamination being forced upon the families living in the projects.

Alongside these physical neighborhood concerns, residents were subjected to menial and sub-par living conditions, ones that were offered to them as a direct result of their lower-class status. They were ignored by the bureaucratic institutions that established welfare policies and were often blamed as the cause of unsafe and dilapidated neighborhoods. Labeled as a "culture of poverty" by critics, blighted neighborhoods

\footnotetext{
${ }^{51}$ K'Meyer, 72.

${ }^{52}$ The Report, 1961.
} 
inhabited by black families were assumed to be the result of poor black mothers' deviant behavior and the accompanying disorganization of familial structure and criminal behavior by black men. ${ }^{53}$ Dorothy Roberts further examines the causes of black women's socially constructed circumstances in her book, Killing the Black Body. She states that it was assumed by city officials and welfare officers that black mothers were responsible for their situation because they "damaged their families in two ways: they demoralized black men and they transmitted a pathological lifestyle to their children, perpetuating poverty and antisocial behavior from one generation to the next." ${ }^{, 54}$ Undoubtedly, this negative stereotyping of women living in these communities was fueled by their social status as welfare recipients, resulting in few neighborhood investments by governing city officials.

Taking note of injustices such as these, Louisville's public housing residents faced what some scholars have called the "interlocking oppression" of discrimination based on class as well as race and gender. ${ }^{55}$ Patricia Hill Collins writes extensively on this phenomenon. She says, "The oppression experienced by most black women is shaped by their subordinate status in an array of either/or dualities. Afro-American women have been assigned the inferior half of several dualities, and this has been central to their continued domination." 56 Black women living in public housing communities most certainly experienced this sort of multiple interlocking oppressions, as they were confined

\footnotetext{
${ }^{53}$ Williams, Rhonda Y., The Politics of Public Housing Black Women's Struggles against Urban Inequality. New York: Oxford University Press, 2004, 128, 127

${ }^{54}$ Roberts, Dorothy E. Killing the Black Body: Race, Reproduction, and the Meaning of Liberty. New York: Pantheon Books, 1997., 16.

${ }^{55}$ Collins, Patricia H. "Learning from the Outsider Within: The Sociological Significance of Black Feminist Thought." Social Problems 33, no. 6 (1986): 14-32.

56 Ibid., 18.
} 
to a lower class status as a result of them being black welfare recipients and mothers. In fact, negative stereotyping of these mothers in the larger American culture took on new heights at this time soon after the beginning of the WOP. With the release of the 1965 Moynihan Report, Senator Daniel Patrick Moynihan, although he was a liberal democrat, identified what he called a black matriarchy which held single black mothers facing poverty the ones responsible for the decline of the black family. ${ }^{57}$ The black mother was said to have been overbearing and thus at fault for emasculating black fathers and limiting their wage earning potential. The consequences of this report pathologized the social position of black mothers and demonized them as Collins, Roberts, and others have addressed.

Before and throughout the local War on Poverty, women activists and their community actions were frequently profiled by liberal news outlets such as the highly respected daily newspaper, The Courier Journal, and its afternoon companion, The Louisville Times, as well as the city's African American weekly, The Louisville Defender. ${ }^{58}$ In her work on Louisville's Civil Rights movement of this era, Tracy E. K'Meyer notes the impact these news outlets had on social change. She reports that "J. Harvey Kerns, in his 1948 study of social conditions in Louisville, reported that the editorial position of these papers 'molds public opinion in favor of better race relations." "59 But the articles examined for this study demonstrate a different side to the story. While the larger public was, in fact, made aware of the larger issues in public

\footnotetext{
${ }^{57}$ Roberts, 16.

58 "Dear Lemme." The Louisville Times, June 15, 1966.; "Housing Applications Must Be Up To Date." The Louisville Times, May 14, 1964.; "Illegitimate Children Are Housing Bar." The Louisville Times, March 10, 1966.

${ }^{59}$ K'Meyer, 8.
} 
housing communities and the widespread discontent those problems evoked, the tone with which journalists represented public housing activists and the mothers who lived in project communities, at times, reinforced negative stereotypes of the "lazy" or "immoral" welfare mother of the sort portrayed of the sort portrayed in Roberts's work. ${ }^{60}$

In a Louisville Times column called Lemme Doit, women seeking answers to why they had not received suitable housing units wrote to the author detailing the deplorable living conditions and mistreatment by landlords being experienced by their families. ${ }^{61}$ Appearing first in the Louisville Times, Lemme Doit dates back to at least the early 1960's with its final home base being in the Courier-Journal. This column was written by an anonymous author who was obviously well connected with the administration of the city government, and it appeared in a section of the newspaper devoted to answering citizens' questions pertaining to issues they had with agencies such as the City Hall and the Municipal Housing Commission (MHC). The Lemme Doit columnist utilized his/her connections with the city government to get more specific responses to these grievances, and published them in a source that would be accessible to the larger community. As author, Lemme promised to find answers to any question in relation to City Hall complaints.

In columns published throughout the 1960's, each time Lemme responded to a mother's letter, he delivered his reply with an accusatory response supported by an official at the MHC, typically Lloyd T. Spies. It always seemed to be the mother's fault as to why her applications went missing, she was no longer eligible for assistance, or she

${ }^{60}$ Roberts, 111.

61 "Dear Lemme." The Louisville Times, June 15, 1966.; "Housing Applications Must Be Up To Date." The Louisville Times, May 14, 1964.; "Illegitimate Children Are Housing Bar." The Louisville Times, March 10, 1966. 
simply had too many illegitimate children. As noted above, through this media outlet, the larger public was made aware of the conditions in which women and children were living, and the discriminatory housing policies enforced upon them. But even as it gave public housing residents a forum to publicly address their concerns with the upper echelons of the MHC, the voice of the Commission reinforced negative stereotypes of mothers receiving welfare. And, consequently, the concerns of the women relying on housing subsidies were sidelined and received negative feedback in terms of their living conditions and thus found little help in Spies's proposed suggestions for attaining housing.

In many Lemme Doit columns of this era, women made claims that they had been unjustly overlooked for suitable living quarters in public housing communities, but in the replies of their complaints often provoked negative stereotyping and devaluating of mothers receiving welfare. One mother wrote in a letter published in the Louisville Times on March 10, 1966, "The housing people tell me a woman with two children or more can't live in the projects when the head of the family is not going to be in the home." ${ }^{62}$ Officials from the Municipal Housing Commission (MHC) confirmed that due to policies dating back to before 1955; women living in project housing communities were not permitted to have more than one illegitimate child living in the home. ${ }^{63}$ Seemingly, women's lives were dictated by such socially biased viewpoints, and it was these kinds of bureaucratic pressures that neighborhood women had to work against. In the same article mentioned above, "In Need" asks, "What are the projects for, if not for people in my

\footnotetext{
62 "Illegitimate Children Are Housing Bar." The Louisville Times, March 10, 1966. 63 Ibid.
} 
condition?" ${ }^{64}$ Lemme responded with a report from Spies claiming that, "It's not true that mothers of two or more children can't get a housing unit unless her husband is in the home," and that "nearly 35 percent of Louisville's nearly 5,000 public housing units are occupied by families in which the head of the family is a woman. They may be widows or divorcees" The reason, Spies claimed, was that "[m]ore than ten years ago the commission adopted a policy of admitting a family with one child born out of wedlock, but of barring any with more than one such instance." ${ }^{65}$ Lemme's column concluded by reporting that the rule might be harsh, but that "the commission [felt] a responsibility to its other tenants to avoid conditions that might be distasteful or embarrassing to them."

This same issue arose in another Lemme Doit column appearing a few months later, on June, 15,1966 . In this article "Desperate" wrote to Lemme asking why she had to have her estranged husband sign for her to get a public housing unit. She stated that she and her five children were receiving \$148 a month from ADC and were residing in an unsafe home where rats were common and twice someone hard tried to start a fire on her front door step. Again, Lemme responded with a statement from Spies reporting that "the Commission will accept an application where there is one child born out of wedlock, but it refuses an application where there are two or more. ${ }^{, 67}$ In "Desperate's" case, "there is a question of two or more," and "furthermore, [her] husband [was] not in the home." 68 This housing restriction appeared to have applied only to mothers of multiple illegitimate children. Singling them out in this way, besides providing a concrete example of black

\footnotetext{
64 "Illegitimate Children Are Housing Bar." The Louisville Times, March 10, 1966.

65 Ibid.

66 Ibid.

67 "Dear Lemme." The Louisville Times, June 15, 1966

68 Ibid.
} 
feminist scholars' claims about multiple of interlocking oppression, suggests that their particular experiences with motherhood as unmarried women resulted in discriminatory treatment against them by bureaucrats who wielded undue moral authority to determine who was worthy of assistance and who was not. Commission policy was clearly guided by what Roberts identifies as "behavior modification rules" intended to sanction what was often understood as the unruly sexuality of poor women of color. ${ }^{69}$ Based on Spies' responses to "In Need" and "Desperate", it is clear that this policy was applied to women who were not legally determined to be single, without any support from a man. They were only assumed to be worthy of government support if their children's well-being was entirely dependent on welfare. As noted before, by giving a voice to the housing authority, as well as to the families affected by the agency, these responses made it clear to the applicants, and to the general public, that the actual welfare of the family was not the first priority of Commission policies.

Countering these and other negative stereotypes of black women, public housing residents drew from community support to bring attention to these unsafe living conditions experienced by their families. This grassroots activism was directly motivated by their unique experiences of poverty and the potential for partnerships that were sustained by the mixed-class communities of African Americans in Louisville's west end. As noted above, both poor and middle-class black communities in Louisville have since the 1950's been (and largely still remain) confined to west end and downtown neighborhoods. In terms of public housing communities in the western and downtown

\footnotetext{
${ }^{69}$ Roberts, Dorothy E. Killing the Black Body: Race, Reproduction, and the Meaning of Liberty. New York: Pantheon Books, 1997, 207.
} 
part of the city during the WOP era, the Southwick, DuValle, Cotter/Lang Homes and Beecher Terrace projects had housed mixed-class black families since at least 1940, and like their middle-class counterparts living outside of project housing communities, these locations also happened to rest in the least improved parts of town. ${ }^{70}$ Since both middleclass and poor residents lived in the same communities, it is likely that many of them shared similar views of the deplorable living conditions experienced by their fellow community members. Countless residents cited lack of access to recreational and medical facilities, rat infestation, and minimal police protection as areas of primary concern for west end residents. ${ }^{71}$ Illustrating the effect this had on the whole of the west end, Ruth Bryant, an influential member of the West End Community Council (WECC), asserted that the multifaceted issues of poverty and poor living conditions in the west end were a problem felt by all that lived in these communities. Addressing such matters, writers of that 1961 Report encouraged the Mayor's office to organize with church leaders, community pastors and other political leaders in these ignored parts of town. ${ }^{72}$

Recognizing the limited authority of the Committee due to their volunteer status as a group, the Report authors placed emphasis on what would come to be known as “maximum feasible participation" of poor people within grassroots organizations. ${ }^{73}$ Fairly

\footnotetext{
70 Louisville Metro Human Relations Commission. Making Louisville Home For Us All: A 20-Year Action Plan For Fair Housing. Louisville, KY, 2013.

${ }^{71}$ Billiter, Bill. "Protesting Tenants Pack Housing Panel Meeting." The Courier Journal (Louisville), January 22, 1969.; "Housing Area Up In Arms About Locks." The Louisville Times, May 19, 1966.; "Mildly, Angrily, Southwick Residents Tell Their Woes." The Courier Journal (Louisville), April 9, 1965.; "Southwick Group Takes Fight To Mayor, Alderman." The Louisville Defender, June 4, 1964.; "Southwick Leaders Ask Pool, Clinic, Substation." The Louisville Times, August 16, 1966.; "Southwick Residents Unite Against Crime." The Louisville Times, January 1, 1966.; Wells, George. "Lights, Locks, Criticized: Beecher Terrace Residents Ask Action to Halt Break-ins." The Courier Journal (Louisville), March 22, 1966.

72 The Report, 1961.

73 Ibid.
} 
well-to-do African American women such as Walls, who had once sat on the housing sub-committee for the Mayor's Committee on Human Rights and was also a prominent member of the Human Relations Commission, became a primary source of support for women organizers living in public housing communities. During the mid-1960's, Walls was employed as the supervisor of the tenant selection committee for the MHC, and her involvement in women's neighborhood activism established avenues for black political activists to initiate community action initiatives. Although her community action was targeted primarily at supporting racial integration, Walls's dedication to grassroots activism established pathways for other black and low-income neighborhood women to become involved in political arenas. ${ }^{74}$ Her presence in local politics legitimized the need for the voices of black women in Louisville.

Another influential middle-class activist who promoted the needs of the public housing residents was Ruth Bryant. Like Walls, Bryant enjoyed a privileged social position in comparison to her fellow working-class community members. In an oral history conducted in 1977, Bryant reports that her motivation to become involved in the community was initially brought on by her husband, Dr. Roscoe Bryant. He encouraged her to take on a community project because it was expected of the black wives of doctors in their middle-class social circle to promote the needs of the total black community. ${ }^{75}$ Bryant began her community action with the Urban League and the Human Relations Commission; and unapologetically, she identified her "pleasing appearance" and ability

\footnotetext{
${ }^{74}$ Interview with Murray Walls, July 27, 1977, Oral History Center, University of Louisville Archives and Records Center, Louisville, Kentucky.

${ }^{75}$ Interview with Ruth Bryant, July 24, 1977, Oral History Center, University of Louisville Archives and Records Center, Louisville, Kentucky.
} 
to clearly articulate the trouble of the black community as among her best sources of effectiveness in the local political arena. ${ }^{76}$

Bryant's oral history is valuable to this study as it clearly identifies the class struggles between grassroots activists and the city officials. Her statements shed light on the lack of attention paid to the poor and public housing residents in her community by government officials, thus confirming some residents' accusations that public housing residents were treated as second class citizens. Additionally, Bryant's narrative of the War on Poverty identifies the emergence of new class conflicts between middle-class organizers and public housing neighborhood organizations. ${ }^{77}$ This phenomenon is also apparent in the Durham case study. Christina Greene writes, "The broader class divisions that had long plagued Durham's black community were reproduced within the Black Solidarity Committee (BSC) and centered on both low-income black women's determination to make poverty a major focus of the boycott and their persistent criticism of the BSC's middle-class bias." ${ }^{, 78}$ Although Bryant identifies major neighborhood improvements as a result of this mixed-class neighborhood organizing, she is also forthright about the struggles poor women of color faced when the notion of maximum feasible participation became an essential component of anti-poverty programs. Bryant reported that at meetings conducted by the anti-poverty commission, professional men sitting on anti-poverty boards such as Booker Robinson and Robert Whiner employed the assumption that poor people committed crimes and that was reason enough for them to

\footnotetext{
76 Ibid., 14.

77 Ibid., 26.

${ }^{78}$ Greene, Christina. Our Separate Ways: Women and the Black Freedom Movement in Durham, North Carolina. Chapel Hill: University of North Carolina Press, 2005., 166.
} 
claim that the input of voices of public housing residents would be counter-productive to the improvement of blighted communities. ${ }^{79}$

Walls and Bryant, as well as the other men and women serving on the West End Community Council, worked closely with public housing residents in their organizing efforts on a variety of issues. It appears that due to the socially biased politics of local city officials and their offices, public housing activists were somewhat dependent on the grassroots activism of these middle-class women living outside of their projects. As in the case of Durham, Greene notes, "low-income and elite blacks needed one another." 80 Although my research illustrates that the grassroots activism of public housing residents and poor women of color pre-existed the community action of neighborhood groups such as the WECC, it was the partnership between the two classes that legitimized the need for a political presence of those living in poverty. With the declaration of the War on Poverty in January of 1964, neighborhood women's grassroots organizations, like the Southwick Improvement Club (SIC) (examined at more length in Chapter Two), utilized the political clout awarded to women such as Walls, Bryant, and the WECC to expand their organizing efforts and obtain federal anti-poverty funds aimed at sustaining their neighborhood organizations.

\footnotetext{
${ }^{79}$ Bryant, (Oral History), 25.

${ }^{80}$ Greene, 172.
} 


\section{CHAPTER TWO}

Activist-minded women in Louisville's housing projects organized and communicated their public housing concerns to the larger community prior to and independently of the 1964 implementation of the War on Poverty. Due to public housing residents' particular social locations as discussed in Chapter 1, their organizing efforts were often distinct in comparison to those of other neighborhood groups such as the West End Community Council (WECC) and the women who led these groups, such as Murray Walls and Ruth Bryant. Coming together due to common problems they faced, black women living in Louisville's west end worked across class differences to improve their neighborhoods. In doing so, they often drew from their shared identities as black mothers to locate the roots of their oppression and to identify avenues through which they could initiate social and physical change in their neighborhoods. ${ }^{81}$

Answering the call for community action articulated in the Report, the antipoverty movement began emerging in the early 1960's as a viable outlet through which public housing residents could organize publicly and collectively and seek funds for

\footnotetext{
${ }^{81}$ Nadasen, Premilla. Rethinking the Welfare Rights Movement. New York: Routledge, 2012.; Naples, Nancy A. Grassroots Warriors: Activist Mothering, Community Work, and the War on Poverty. New York: Routledge, 1998.; Orleck, Annelise, and Lisa Gayle Hazirjian. The War on Poverty A New Grassroots History, 1964-1980. Athens: University of Georgia Press, 2011.
} 
sustaining their organizations. As noted in Chapter One, the Mayor's Committee on Human Rights and its 1961 Report identified as necessity the development of cross-class community action groups to effectively promote the cause of integration and the antipoverty movement growing in Louisville's west end. ${ }^{82}$ The community action groups promoted by this Committee and the volunteer activists who generated the Report should partly be credited with the emerging grassroots activism in Louisville's public housing communities in the coming years. My research has shown that with the help of seasoned middle-class Civil Rights activists such as Walls and Bryant, public housing residents accepted leadership from neighborhood groups outside of the projects (especially the West End Community Council, or WECC) to expand their community action efforts. Although poor women's public housing activism pre-existed the more strategically sound community action groups such as the WECC, essentially it was the partnership between the two classes that effectively implemented the War on Poverty in Louisville.

According to various oral histories and news articles, in Louisville, neighborhood women's organizing of mother's clubs served as some of the earliest grassroots organizations in public housing communities. ${ }^{83}$ As early as 1958 , groups led primarily by poor black women utilized City Hall meetings and media outlets to bring attention to the

\footnotetext{
${ }^{82}$ Committee On Human Rights. Report of the Mayor's Committee On Human Rights. Walls Papers: University of Louisville Archives, 1961. Accessed September 12, 2012.

${ }^{83}$ Interview with Ruth Bryant, July 24, 1977, Oral History Center, University of Louisville Archives and Records Center, Louisville, Kentucky.; "City Promises Southwick Area in Help Relieving Conditions." The Louisville Defender (Louisville), April 15, 1965, 2.; Interview with Benetha Ellis by David Cline, May 11, 2006 , U-0149, in the Southern Oral History Program Collection \#4007, Southern Historical Collection, Wilson Library, University of North Carolina at Chapel Hill.; "Southwick Group Takes Fight To Mayor, Alderman." The Louisville Defender, June 4, 1964.
} 
issues they experienced as recipients of Aid to Dependent Children (ADC) ${ }^{84}$ Illustrating this community action, during the mid-1960's, women like DeMorris Calvin, a resident of the Southwick housing projects, demonstrated the desire to politically organize on behalf of her role as a "good mother." Calvin was a member of what the Courier Journal and the Louisville Defender often referred to as "mothers clubs." These mothers' clubs formed neighborhood groups to discuss the dangerous living conditions in which they were raising their families and to identify avenues through which they could make their complaints to the public. Speaking out on behalf of the children in the community and on matters of personal safety, women in these mothers' clubs reported that they felt that they were treated as second class citizens. In a Louisville Defender article documenting a neighborhood clean-up led by Calvin and her affiliated mothers' club, the Southwick Improvement Club (SIC), she affirms this claim by stating that "Southwick residents want the respect and concern that is due to them as citizens." 85

Benetha Ellis's and Ruth Bryant's oral histories recalls that women living in the Southwick, Cotter Homes, and DuValle public housing communities organized mother's clubs to mobilize community action in the beginning stages of the anti-poverty movement in Louisville. Supporting this claim, in a Courier-Journal article appearing in 1965, Calvin, chairwoman of the SIC, is quoted as saying that public housing residents had been making requests for neighborhood improvements for "the past six or seven years." Unfortunately their repeated requests for help from city hall went unanswered. Mothers

\footnotetext{
84 "Dear Lemme." The Louisville Times, June 15, 1966.; "Mildly, Angrily, Southwick Residents Tell Their Woes." The Courier Journal (Louisville), April 9, 1965.; "Southwick Group Takes Fight To Mayor, Alderman." The Louisville Defender, June 4, 1964.

85 "City Promises Southwick Area in Help Relieving Conditions." The Louisville Defender (Louisville), April 15, 1965, 2.

86 "Mildly, Angrily, Southwick Residents Tell Their Woes." The Courier Journal (Louisville), April 9, 1965.
} 
in these clubs organized amongst themselves to represent their group's mission at meetings with the Board of Alderman and other city agencies. ${ }^{87}$ They organized on behalf of their small community's particular social ills and formulated ways in which to combat the main issues such as rats, dumping sites, and minimal police protection among other things. ${ }^{88}$ In the Louisville Defender profiling Calvin's community action, the author also reported that "the Southwick mothers have expanded their work to enlist the help of the men in the project and are now calling themselves the Southwick Improvement Club." After organizing meetings to discuss their individual concerns and subsequent action steps, these mothers eventually planned meetings with their landlords and city officials to voice their concerns. ${ }^{90}$ Supporting this claim, Ruth Bryant recalled in an interview that the women of Southwick "knew their way around City Hall better than a lot of upper middle-class citizens. They had been trying to get things done for years.",91

Women from the Southwick and Cotter homes housing projects, and the Colonial Park private housing community comprised the membership of the mothers clubs that were eventually organized into SIC. Moreover, in1964, a sub-committee was formed within the Southwick's neighborhood club called the West End Advisory Committee (WEAC). ${ }^{92}$ The Louisville Times situated WEAC as an official group recognized by city officials, charged with preparing proposals and formally submitting grievances at City Hall and other community venues. ${ }^{93}$ Such articles suggest that while the federally funded

\footnotetext{
87 Ibid.

${ }^{88}$ Ibid.; "Southwick Group Takes Fight To Mayor, Alderman." The Louisville Defender, June 4, 1964.

89 "City Promises Southwick Area in Help Relieving Conditions." The Louisville Defender, April 15, $1965,2$.

90 "Southwick Group Takes Fight To Mayor, Alderman." The Louisville Defender, June 4, 1964.

91 Bryant, R., (Oral History), 17.

92 "Southwick Group Takes Fight To Mayor, Alderman." The Louisville Defender, June 4, 1964.

93 Ibid.; "Southwick Leaders Ask Pool, Clinic, Substation." The Louisville Times, August 16, 1966.
} 
City-County Action Commission (CAC), promoted through the CAP, was actively working in public housing communities in partnership with residents and neighborhood clubs, the community action of SIC preceded the influence of CAC's involvement. According to the recollections of Bryant, Ellis, and Georgia Eugene, most of the CAC and CAP funds were aimed at the community action of the DuValle target neighborhood. From these observations by key women leaders, it can be assumed that SIC and WEAC were sustaining their community action efforts independently of the developing CAC in Louisville.

Growing alongside SIC's developing constituency were members' troubles with the dumping site located across from their community, a problem that had been brewing since the mid 1950's. In the Louisville Defender article mentioned above, the author reported that DeMorris Calvin, then Chairwoman of SIC and the leader of the Southwick neighborhood cleanup, reported that the dumping site located at $35^{\text {th }}$ and Bhone had been intended for commercial development as part of the urban renewal plan, but that in fact "outsiders and business firms were dumping trash in the area." communities insisted to officials that their neighbors and nearby residents were not the ones responsible for the dumping, contrary to popular opinion. Through these mothers' club's investigations, organizers apparently found that people from other regions of the city were traveling to the west end to get rid of trash, which club members took as an indication of the city's treatment of their community members as second class citizens. Unfortunately, this issue was taken seriously only after the more well-respected WECC member, Ruth Bryant, took notice of the unsightly lot on her way to take her daughter to

\footnotetext{
94 "City Promises Southwick Area in Help Relieving Conditions." The Louisville Defender, April 15, $1965,2$.
} 
school. ${ }^{95}$ She is reported to have taken the issue to the Mayor's office herself, but only after WECC became involved, supported by funds from the WOP and the CAC did any form of success take place. ${ }^{96}$ Bryant states that she personally took the issue to the committee she was sitting on, the Mayor's Advisory Committee, but initially gained little respect for the problem or for the people affected by the dumping site. According to Bryant's oral history, she then partnered with Sister Marcella, principal of the Christ the King School, to take charge of this issue and to develop an unnamed sub-committee within WECC to work with the women in the Southwick neighborhood. ${ }^{97}$ Through collaboration with the Southwick neighborhood club women, Bryant, Sister Marcella, and the WECC eventually saw to it that the trash was removed by the grassroots organizations invested in the cause. ${ }^{98}$

The need for recreational facilities was also a major concern for SIC community members before and throughout the War on Poverty. Their activism surrounding this issue is documented in local newspapers from 1964 to 1966. The Louisville Defender first reported in mid-1964 that "the Southwick group" had backed a "drive asking the city recreation department to build what they termed 'needed facilities' to accommodate the approximate 1,000 children in the area." ${ }^{99}$ As mentioned earlier, the SIC mobilized community action among housing residents, and formed the West End Action Committee (WEAC) to explore options for recreational development ${ }^{100}$ The work of WEAC

\footnotetext{
${ }^{95}$ Bryant, R,. (Oral History), K'Meyer., 157.

${ }^{96}$ Bryant, R., (Oral History), 18.

${ }^{97}$ Ibid, 16.

98 Ibid, 17.; "City Promises Southwick Area in Help Relieving Conditions." The Louisville Defender, April 15, 1965, 2.

99 "Southwick Group Takes Fight To Mayor, Alderman." The Louisville Defender, June 4, 1964.

100 Ibid.
} 
appeared again in relation to the cause of recreation facilities in the1966 Times article. In this piece, a Mrs. Carl Bryant, chairwoman of WEAC, proposed a much longer list of demands for community improvement in comparison to the 1964 list of demands. A comparison of these events to those discussed in the oral histories of community organizer Lula Hodges, a paid community organizer through the CAC, and Ruth Bryant suggests that the work of SIC and WEAC took root prior to the new infusion of funds that accompanied the implementation of WOP in Louisville. Moreover, it appears that the Southwick group eventually benefited from WOP funds and well-supported neighborhood groups such as WECC after official implementation of CAP and the development of the local CAC. ${ }^{101}$

The activism of SIC independent of WOP and CAC initiatives was also documented in t Courier-Journal in April of $1965 .{ }^{102}$ This article highlighted the mounting fury of Southwick housing project residents at a community meeting. At an hour long open house with city officials at City Hall, Southwick residents, represented by Calvin, tenaciously voiced demands for improved living conditions. Calvin represented at least 100 residents, and she cited rat infestations, limited police response, and the need for economic growth as some of their primary complaints. Residents made it clear to city officials that the administration's lack of concern was glaring, and would not be tolerated. In response, Aldermanic President Kenneth A. Schmied instructed the residents to form yet another sub-committee to meet with officials and discuss the issues plaguing the neighborhoods. As illustrated in subsequent news coverage, Southwick residents took the

${ }^{101}$ Interview with Lula Hodges by David Cline, June 2, 2006, U-0114, in the Southern Oral History Program Collection \#4007, Southern Historical Collection, Wilson Library, University of North Carolina at Chapel Hill.

102 "Mildly, Angrily, Southwick Residents Tell Their Woes." The Courier Journal (Louisville), April 9, 1965. 
advice of city officials, coordinated meetings, and developed proposals for neighborhood developments. $^{103}$

The issue of minimal and inadequate police protection was yet another major concern for Southwick and Cotter Homes residents. Informal interviews with former residents illustrate the confined landscape they perceived of their environments.

According to one former resident, "there was one way in, and one way out.",104

Confirming this claim, another former resident stated that this enclosure separated dense communities from police patrolling areas thus inviting an increase in neighborhood crimes. ${ }^{105}$ The Times reported in January 1966 that there was evidence of women's neighborhood organizing in support of more police protection as a result of these unsafe neighborhoods. ${ }^{106}$ Another committee within SIC was formed to reduce crime in the area. Georgia Stevenson chaired the committee, and was tasked with "encourag[ing] support for the law, and to support those who will work with the police to reduce crime in the area" ${ }^{107}$ Residents foregrounded the collective responsibility of public housing residents to address neighborhood crime. This notion of collective responsibility is also apparent in the words of one mother attending a resident's council meeting in 1969 who asserted, "I think before we put all this blame on the children we ought to try and clean up some of the adults." 108

\footnotetext{
103 Billiter, Bill. "Protesting Tenants Pack Housing Panel Meeting." The Courier Journal(Louisville), January 22, 1969.; Crowdus, Vincent. "City Hall Delegation Checks Southwick Area Complaints." The Louisville Times, April 16, 1965.; "Housing Area Up In Arms About Locks." The Louisville Times, May 19, 1966. ${ }^{104}$ Powers, Glenda, former Cotter Homes resident, interview by Aletia M. Robey, January 12, 2014. 105 Jones, Louise, former Cotter Homes resident, interview by Aletia M. Robey, January 12, 2014.

106 "Southwick Residents Unite Against Crime." The Louisville Times, January 1, 1966.

107 Ibid.

108 Riehm, Joan. "Housing Councils Give The Tenants a Voice." The Courier Journal (Louisville), June 22, $1969,1,5$.
} 
Another notable voice in the public housing communities was that of Venice Hunter. Hunter was a resident of the Cotter homes project who became a leader for change in her community and member of another community group located in the target area of DuValle that pre-existed WOP funded community action: the Harris Neighborhood Improvement Club (HNIC). Hunter was the president of this club, which accompanied her on here demonstration for a new traffic light in 1966. During that conflict, Hunter, a widow, asserted HNIC had "tried without success for two years to get a light" installed at the intersection of Wilson Avenue and DuValle Drive. ${ }^{109}$ They had "got up a petition asking for the light in August of 1964 and collected 3,000 signatures" with no response from city officials. ${ }^{110}$ As SIC had done, HNIC organizers met with fellow residents to identify and discuss issues facing the total community and subsequently developed plans to incite action around the need for a traffic light. This illustrates how the women were well organized and "volatile." "111 According to Benetha Ellis, who became a CAC paid organizer in 1966, "they wanted to be heard, and they were kind of leery of 'outsiders', as they called it, coming in and telling them what they wanted to do, what they wanted to put in their neighborhoods, because they wanted to implement it in their own way, knowing what was really needed." ${ }^{112}$ According to this article and the story offered by Ellis, the HNIC and Hunter's community leadership were active beginning around 1964 prior to the official implementation of the War on Poverty in Louisville. Indeed, this research has illustrated that it was not just the peaceful

\footnotetext{
109 "Traffic Stopper." The Louisville Times (Louisville), May 16, 1966.

110 Ibid.

111 Interview with Benetha Ellis by David Cline, May 11, 2006 , U-0149, in the Southern Oral History Program Collection \#4007, Southern Historical Collection, Wilson Library, University of North Carolina at Chapel Hill.

${ }^{112}$ Ellis., (Oral History), 5.
} 
collaboration with CAC through which Hunter and HNIC made progress. It was not until 1966 that their group demonstrated any form of success through their use of the coordinated protest that found Hunter in jail and receiving her highly publicized one dollar fine. $^{113}$

A textual analysis of news articles and oral histories reporting on Louisville women's public housing activism demonstrates that various neighborhoods rallied for their own individual causes in terms of total community improvement. Compared to the women who organized later in Beecher Terrace (as detailed in Chapter Three), the women of Southwick and Cotter Homes appear to have worked the most independently prior to and throughout the War on Poverty in Louisville, focusing their attention on rat infestation, dumping sites located disproportionately in their communities, and few recreational facilities for neighborhood children. Although sources suggesting that women such as DeMorris Calvin and Vernice Hunter worked along-side the CAC, there is little evidence of their activism being directly promoted or financially supported by the CAC. In an article appearing in the Courier Journal reporting on the effects of the WOP in Louisville in 1966, the CAC actually attributed the eventual success surrounding the traffic light to Hunter and her demonstration ${ }^{114}$ The neighborhood organizing of the Harris Neighborhood Improvement Club and the founding mothers of the Southwick Improvement Club can be traced back to as early as 1964 for the former, and back even earlier, to 1958, for the latter- occurring before the official proclamation of Johnson's War on Poverty in August of 1964. Although the Louisville Times drew a connection in

\footnotetext{
113 "Traffic Light Set for DuValle, Crusader Informed." Courier Journal (Louisville), July 13, 1966.; "Traffic Stopper." The Louisville Times, May 16, 1966.

${ }^{114}$ Grieder, William. "The Poor Speak Out." The Louisville Times (Louisville), July 25, 1966.
} 
its 1966 coverage between CAC initiatives in the DuValle target neighborhood and Hunter's success, the findings discussed here suggest that her community action preceded the implementation of the Community Action Program in Louisville. This point of contention provides opportunities to illustrate how the WOP changed and gave added weight to local women's neighborhood activism.

The following chapter turns to an analysis of the work of local CAC paid community organizers and the resulting neighborhood clubs such as The Beecher Terrace Improvement Club, the Citywide Resident Council, and the Tenant Relations Commission. Networks like these laid the groundwork for more sophisticated and mass actions that the WOP would enable. Their organizing strategies, along with their many success and some failures lead to new conclusions about of how the War on Poverty impacted women's housing activism throughout the 1960s. 


\section{CHAPTER THREE}

By 1964, Louisville neighborhood women's organizing had established a solid political presence for their communities in City Hall. Neighborhood groups like the Southwick Improvement Club and the Harris Center Improvement Club worked collectively among residents and with their middle-class allies prior to the implementation of the Community Action Program in Louisville and also at a more localized level than the work of groups like the West End Community Council (WECC). ${ }^{115}$ With the assistance of community organizers paid through the City-County Action Commission (CAC), after 1964 groups such as the Beecher Terrace Improvement Club (BTIC), the Taylor Progressives Club, and the City-Wide Resident Council were formed, and they expanded upon the organizing efforts of the existing neighborhood clubs examined in Chapter Two. This development increased people power and also boosted resident involvement in the development of bureaucratic policy making. Consequently, the Municipal Housing Commission (MHC) established a Tenant Relations department to serve as a liaison between these organized tenants and housing

\footnotetext{
${ }^{115}$ Adams, Luther. Way Up North in Louisville African American Migration in the Urban South, 1930-1970. Chapel Hill: University of North Carolina Press, 2010.; K'Meyer, Tracy E. Civil Rights in the Gateway to the South Louisville, Kentucky, 1945-1980. Lexington: University Press of Kentucky, 2009.; K'Meyer, Tracy E. "The West End Community Council: Building Interracial Community in Louisville's West End." Ohio Valley History 7, no. 3 (2007): 6-31.
} 
officials. In terms of the longevity of the SIC, CAC had a profound impact on the community organizing in Southwick and the DuValle neighborhoods. The SIC and its sister organizations made some drastic changes in their neighborhoods; but they also witnessed a dissolution of trust among community members. In the examination that follows, the emergence of BTIC and other councils illustrates how the CAC both promoted the cause of neighborhood women's organizations, and, as in the case of SIC, somewhat divided these activist women in resident clubs from their middle-class allies.

Built in 1940 and initially open only to black families, the Beecher Terrace public housing community sat directly between the border of the downtown business area and the edge of the west end of Louisville. ${ }^{116}$ Despite the move towards integration in Louisville during this era, as noted in the Report, public housing communities remained slow to integrate. By 1966, Beecher Terrace housed some 2,118 residents in 808 apartments. ${ }^{117}$ Coping with similar problems as Southwick in the western part of town, Beecher Terrace residents formed the BTIC and the Taylor Progressive Clubs in 1966 with the help of paid community organizer Charles Vittatow. ${ }^{118}$ Through formal meetings with housing officials and the development of educational materials, most notably the Tenant Rights book published in 1970, resident activists initiated a dialogue between them and officials to voice their concerns over the unsafe living conditions in their community. ${ }^{119}$ Partnerships with CAC organizers and residents manifested actions plans and a means to achieve total neighborhood improvement. Some of their main concerns

\footnotetext{
${ }^{116}$ Louisville (KY). Louisville Metro Human Relations Commission. Making Louisville Home For Us All: A 20 Year Action Plan For Fair Housing. Louisville, KY, 2013, 11.

117 "Beecher Terrace Landlords To Hear Residents' Appeals." The Louisville Times, March 25, 1966.

118 "Beecher Project To Get New Locks." The Louisville Times, May 27, 1966.

119 "Tenants' Rights Book Is Popular With Landlords." Courier Journal (Louisville), June 18, 1970.
} 
were a lack of adequate lighting, faulty door locks, and an increase in home intrusions and burglaries. ${ }^{120}$ Indeed, women living in this community did not organize prior to the implementation of the War on Poverty in Louisville; but this group was also a direct result of the funds paid to hire community organizers through the CAC.

Identifying the BTIC as a "federally supported poverty program," a Louisville Times article authored by George Wells publicized a meeting called by BTIC held at Taylor Elementary on March 25, 1966. ${ }^{121}$ Forty-five residents attended this meeting and publicly addressed the issues plaguing their community to officials of the MHC and their landlords. The following day, in an article headlined "Beecher Residents Ask Action to Halt Break-Ins," the Courier-Journal reported on the outcomes of the meeting and the Commission's response. This article cited BTIC's complaints regarding the need for new locks, more thorough investigations on the high incidents of burglaries, and more street lighting. Additionally, residents said "they were concerned that maintenance men have keys to all apartments."122 The response from city officials was not unlike before. Just as in the Commission's response to Southwick residents' demands regarding the need for increased police protection, recommendations were made for Beecher Terrace residents to take responsibility themselves in reporting suspicious behavior and an increased value placed on respecting the law. According to Wells's reporting of the meeting, Lloyd Spies

\footnotetext{
120 "Beecher Terrace Landlords To Hear Residents' Appeals." The Louisville Times, March 25, 1966.; "Housing Area Up In Arms About Locks." The Louisville Times, May 19, 1966. ; Wells, George. "Lights, Locks, Criticized: Beecher Terrace Residents Ask Action to Halt Break-ins." The Courier Journal (Louisville), March 22, 1966.

121 "Beecher Terrace Landlords To Hear Residents' Appeals." The Louisville Times, March 25, 1966.

${ }^{122}$ Wells, George. "Lights, Locks, Criticized: Beecher Terrace Residents Ask Action to Halt Break-ins." The Courier Journal (Louisville), March 22, 1966.
} 
(speaking as director of management for the commission) said, "'that no one ever sees anything, or if they do, they won't tell us about it.",123

Although women and children comprised the majority of residents living in public housing, city officials challenged them to work with their neighbors and demonstrate to the police that they were worthy of civil protection. According to that same CourierJournal article, Spies also claimed at the BTIC meeting that the "maintenance men are not guilty," and that the "inquiries into burglaries get few results because "no one sees anything, or." ${ }^{, 124}$ By minimizing criminal assault and break-ins, the authorities implied a lack of collective worth for the population living in the housing projects. The publicized communication between the residents and city officials makes apparent to both residents and the larger public that the governing institutions in the city had little respect for the communities they serve. The BTIC's community project to get new locks and street lights appears to have become their primary focus in the following years, perhaps to demonstrate to the Commission that they did indeed value the safety of their neighborhoods and disdained the criminal behavior in their community. As it turns out CAC community organizers and BTIC were successful in achieving those demands.

Three months after the BTIC called their meeting and reported grievances to city officials in regards to the conditions of their homes and the mounting safety concerns, an article in the Louisville Times reported on the official outcomes of that meeting. City officials instructed the residents to purchase their own locks, and promised that the

\footnotetext{
123 Ibid

124 Ibid.
} 
Commission would replace the locks themselves. ${ }^{125}$ Dissatisfied with that idea, BTIC members, in partnership with another neighborhood group called the Taylor Progressives, worked with CAC organizers to have local locksmiths investigate the effectiveness of the locks. Additionally, the groups hired a lawyer to determine whose responsibility it was to replace the locks. Sadie Johnson, president of the BTIC, and Martha Cunningham, president of the Taylor Progressives, both credited with coordinating the investigations and submitting a formal proposal to the Commission, presented the following findings:

A local locksmith looked at a sample of the locks and found them to be "inadequate," noting that the skeleton key would fit all of them with some filing. Another locksmith said the locks should be replaced with doublecylinder locks.

There is a problem of the lost or mislaid keys. Also some keys fit more than one door. The investigators quote a police lieutenant who said in these circumstances new locks would cut burglaries. The doors have windows in them which can be broken, allowing a burglar to unlock an ordinary spring lock. Thus, double-cylinder locks that need a key for operations from either side are recommended. ${ }^{126}$

According to the Times article that covered their proposal, the lawyer hired by the group determined that the housing commission was responsible for replacing the locks as part of "its contractual obligation to maintain the premises. ${ }^{127}$ The BTIC and the Taylor Progressives stated in an accompanying letter to Harold M. Booth, junior director of the housing commission, that they would accept a lock "replacement rate of ten per month, 'until the job is completed, which would be around 1972.",128 Unfortunately, neither that demand nor a formal report was enough, as Spies responded by saying that the Commission would only replace the defective locks because replacing all of them could

\footnotetext{
125 "Housing Area Up In Arms About Locks." The Louisville Times, May 19, 1966.

${ }^{126}$ Ibid.

127 Ibid.

${ }^{128}$ Ibid.
} 
entail a "terrific expenditure." 129 The Commission also claimed that it would have to conduct its own internal investigation in order to determine the necessity of new locks and windows.

As evidenced by the BTIC and the Taylor Progressives' approach to making change in their communities, their clubs' initial organizing efforts appear to have been more sophisticated than those of SIC and WEAC pre-WOP addressed in Chapter 2. This difference appears to be partially due to the former group's support from CAC organizers and the available federal funds. Charles Vittatow's involvement as a federally paid community organizer provided the BTIC and the Taylor Progressives Club with guidance on how to go about contracting with locksmiths and lawyers, and his input provided CAC funds to pay the fees. Additionally, as in the SIC's collaborations with WECC, federally supported pressure from CAC organizers aware of the need for "maximum feasible participation" encouraged officials to respond to their communities concerns.

Notwithstanding the lack of immediate concern from the Commission, the BTIC and the Taylor Progressives Club did eventually achieve success through their efforts. Just one week after club members submitted the formal report and the proposal to get new, more efficient locks, the Commission granted the groups their requests. Booth responded to the group leaders by stating that the Commission had agreed that "all the old locks will be replaced with cylinder-type locks under a long term program- starting within the next 30 days." 130

\footnotetext{
129 Ibid.

130 "Beecher Project To Get New Locks." The Louisville Times, May 27, 1966.
} 
The BTIC's success demonstrated that there was hope for community change through grassroots activism. The group's achievement of attaining new locks for housing units illustrated that women's community involvement with $\mathrm{CAC}$ was beneficial to the public housing communities affected by poverty. By 1966 after the implementation of the CAP in Louisville on a much larger scale, residents of public housing communities began to see that they could affect the bureaucratic methods of decision making. But consequently, the reality of CAC's success in poor communities posed a threat to many of the officials being challenged by BTIC and others. In a Times piece written by William Grieder in 1966, headlined, “The Poor Speak Out: Their words are heard in the poverty war and they often rasp on City Hall's nerves," a local public official is quoted as saying, "People use to say 'You can't fight City Hall,' but now the blank-blank federal government is paying "em to do it." ${ }^{131}$ The agency this official was referring to was CAC, and while there was an obvious tone of disdain for the work of the agency and their resident organizers in the words of the quoted official, there was also an acknowledgement in the rest of Grieder's piece of the increasing amount of achievements coming out of these communities. Grieder editorialized that the neighborhood groups and CAC's "vision of democracy" is "both cynical and romantic," and that "this vision proclaims that all citizens, not just the privileged few with money and education, can be taught the techniques of influencing decisions."132 Grieder attributed much of the success and growth in neighborhood improvements to BTIC's community action and the cause of the War on Poverty in Louisville.

\footnotetext{
${ }^{131}$ Grieder, William. "The Poor Speak Out." The Louisville Times, July 25, 1966.

132 Ibid.
} 
Because federal WOP efforts were still alive and well in Louisville throughout the mid-1960's and thereafter, there was little that city officials could do immediately to squash the organizing efforts of neighborhood women. Constant pressure from the BTIC and others forced the MHC to reconsider how it managed its properties and responded to resident grievances. Harold Booth, Junior Director of the Housing Commission, stated that neighborhood groups had been "extremely vocal in criticizing commission policy and rules," and, consequently, the commission's failures were addressed through the City's attempt at expanding the involvement of residents in MHC policy formation. ${ }^{133}$ ،

In 1968, the MHC accepted $\$ 3.5$ million through the federal anti-poverty program offered to renovate seven of the city's nine public housing communities. A federal regulation stipulating that public housing residents be further involved in forming social welfare programs led to the development of a Tenant Relations department within MHC. ${ }^{134}$ As a component of the $\$ 3.5$ million dollar Model Cities program, and directed by Rev. E. Deedom Alston, this new department's mission was aimed at alleviating tensions between management and resident councils. ${ }^{135}$ In fact, the new department met increasing challenges from well-coordinated protest and the politically emerging resident councils.

On January 21, 1969, for example, 40 men, women, and children from various public housing communities gathered at the Housing Commission's headquarters to protest the lack of attention to their mounting concerns. Some of these protestors' grievances were related to lack of hot water, the Commission's practice of turning off the ${ }^{133}$ Ibid.

134 "Housing Agency Sets Up Tenant Relations Section." The Louisville Times, August 9, 1968.; Riehm, Joan. "Housing Councils Give The Tenants a Voice." The Courier Journal (Louisville), June 22, 1969, 1, 5.

135 Ibid.; Ibid.; Adams, 173. 
heat after 5 p.m., and poor design choices of newly built project buildings. According to a Courier-Journal article written by Bill Billiter the following day, the residents claimed that the tenant relations department had been unsuccessful in mediating their maintenance request with landlords. ${ }^{136}$ Consequently, angry residents demanded an increase in direct communication with project management and enlisted the help of WECC and the Louisville Welfare Rights Organization to assist them in their organizing efforts. ${ }^{137}$ Indeed, protestors claimed that they had received little success through their partnership with the tenant relations department; and, represented by Parkway resident Selma Burch, they demanded that the "commission give copies of its policies, procedures and rent scales to the Louisville Welfare Rights Organization, West End Community Council, and 'all the neighborhood poverty stations.",138 Like SIC and BTIC, these protestors enlisted the help from WECC and other CAC funded anti-poverty groups. It should be noted that shortly thereafter, in February of that same year, WECC submitted a formal list of complaints signed by 80 residents that were in turn rejected by the Commission, which charged that the claims had been over-exaggerated and misrepresented by the WECC. Lloyd Spies, when asked about this charge, said "When it comes down to one of our specific housing units, we don't feel like the neighborhood [groups] can advise us nearly as well as the tenants."139

Just six months after the January protest, a front page article in the CourierJournal written by Joan Riehm on June 9, 1969 examined the emergence and growth of

\footnotetext{
${ }^{136}$ Billiter, Bill. "Protesting Tenants Pack Housing Panel Meeting." The Courier Journal(Louisville), January 22, 1969.

137 Ibid.

138 Ibid.

139 Riehm, Joan. "Housing Councils Give The Tenants a Voice." The Courier Journal (Louisville), June 22, 1969, 1, 5.
} 
seven public housing resident councils representing some 18,000 residents. ${ }^{140}$ According to Riehm, these resident councils held monthly meetings in their communities to address their particular neighborhood concerns, and they were organized in part by the CAC as well as being funded by the $\$ 3.5$ million dollar loan to the MHC. ${ }^{141}$ Officials from the MHC and project landlords attended the meetings in order to collaborate with the councils in suggesting improvements and implementing physical neighborhood changes. Riehm reported that these councils had been running since at least January of 1969, and had been declared a success by the public housing residents who attended the meetings. Quoting a resident council member, she wrote, "It's just so fair. The little person gets the same opportunity as the big person does."142

Some concerns identified by the resident councils were similar to those of SIC and BTIC. But council meetings did more to open up a dialogue among a larger population of community members, thus shedding light on more nuanced concerns for each of the seven project communities. As noted in various statements by local resident organizers in the primary sources used here, the lack of access to recreational activities and the potentially resulting criminal behavior were major concerns for poor mothers living in the projects. ${ }^{143}$ Lucy Stevenson, regular attendant of the Beecher Terrace resident council meetings stated that "We've had several complaints about children getting into mischief, using bad language and other things. Does anyone know how we

\footnotetext{
140 lbid., 1.

141 Ibid., 1.

142 Ibid., 5.

${ }^{143}$ Adams, 65.; Williams, Rhonda Y. The Politics of Public Housing Black Women's Struggles against Urban Inequality. New York: Oxford University Press, 2004., 47, 163.
} 
can control our children and keep them from bothering the neighbors?" 144 Another mother responded by suggesting that the "environment in the project's courtyard contributes to delinquent behavior." 145 This dialogue demonstrates that the resident councils provided a space for greater numbers of women with diverging opinions to publically state their concerns and offer suggestions for alleviating neighborhood problems. Additionally, the MHC and landlords were included in this dialogue, creating the potential for cross-class decision making processes. This type of change met exactly what was demanded of the MHC upon accepting the anti-poverty re-development loans.

The large interest in the resident councils and the growing membership led to the development of the MHC funded Citywide Resident Council in February of 1969. This council was made up of two resident-leaders representing each specific public housing community's resident council. Members met with MHC officials and according to management director, Lloyd T. Spies "enabled residents to participate directly in the Model Cities project modernization program." "146 Just as Rhonda Williams had found in Baltimore, "[t]he existence of [tenant councils] spurred further tenant organizing in individual black and white public housing communities. ${ }^{, 147}$ Despite the obvious challenge to working across class, it was the inclusion of that wider range of voices that made a difference in terms of policy development and community project implementation.

\footnotetext{
${ }^{144}$ Riehm, Joan. "Housing Councils Give The Tenants a Voice." The Courier Journal (Louisville), June 22, $1969,1$.

${ }^{145}$ Ibid., 1.

${ }^{146}$ Ibid., 1.

${ }^{147}$ Williams, 186.
} 
According to Riehm in the Courier-Journal's coverage of this matter, some of the major successes of the Citywide Resident Council included giving Parkway Place residents the chance to decide where they wanted budgeted improvement money to be spent. Rather than the replacing screens and windows as suggested by the Commission, Parkway residents decided they would prefer the funds to be spent on suitable refrigerators. ${ }^{148}$ In addition to this achievement, Riehm reported that there had been an increased presence of the local police force in the neighborhoods at the request of council members, and approval had been gained to extend the acceptable late rent payment date and to eliminate the one dollar monthly charge on refrigerators owned by residents. ${ }^{149}$ Resident councils effectively negotiated with the Housing Commission and achieved substantial neighborhood improvements for public housing residents in Louisville.

From MHC's perspective, the Citywide Resident Council was more effective in dealing with neighborhood complaints than the project management and grassroots neighborhood social action groups. In response to the success of the Council, Spies noted, "We've always listened to complaints, but the residents have never before had a voice in policy formation. We know this was a mistake." $" 150$ This sentiment is also echoed Williams's work on Baltimore's tenant councils. She notes that commissioners attributed the "success of a housing project" to the direction of tenant councils. ${ }^{151}$ Moreover, addressing the earlier organized mothers clubs, Spies said "Loosely organized groups for social purposes have functioned in the projects for years,' but 'the resident councils

\footnotetext{
${ }^{148}$ Riehm, Joan. "Housing Councils Give The Tenants a Voice." The Courier Journal (Louisville), June 22, $1969,1,5$.

149 Ibid., 5.

150 Ibid., 5.

${ }^{151}$ Williams, 168.
} 
operating now let the commission talk with the people on their own level. We can explain our policies and programs through council officers. ${ }^{, 152}$ It appears that for residents to truly have an impact on policy formation, it had to be done through the direction of the MHC council rather than led by the more informal collective actions of neighborhood women.

Notwithstanding the success of the Citywide Resident Council, the collective action among community members was not without complication. MHC Tenant Relations director Rev. Alston was quoted as saying that some resident council members were wary of working with the Tenant Relations department and even Citywide representatives. ${ }^{153}$ This point of contention was also apparent in Baltimore's residents' councils. According to Williams, "tenants wanted to secure managers whom they thought would help them, 'not talk down to them' because they were poor black people. ${ }^{154}$ Similar to this claim, Alston said that the Tenant Relations represented the "The Man," and that some council attendees were fearful of retaliation if they spoke up about their particular grievances. Alston went on to argue "Mistrust keeps some residents away from the council meetings. Some also fear they will be forced to leave the project if they complain too much." ${ }^{, 155}$ Alston made known that despite his direct interest in neighborhood improvement, he was not trusted by the community he was hired to serve. He argued that $\mathrm{CAC}$ organizers were encouraging residents to turn against their neighborhood councils. Although MHC officials perceived residents' lack of trust of the

152 Riehm, Joan. "Housing Councils Give The Tenants a Voice." The Courier Journal (Louisville), June 22, $1969,5$.

153 Ibid. 5 .

${ }^{154}$ Williams, 168.

${ }^{155}$ Riehm, Joan. "Housing Councils Give The Tenants a Voice." The Courier Journal (Louisville), June 22, 1969, 5. 
Commission as slowing down neighborhood progress, residents' organizing efforts can still be appreciated for the lasting changes that were made.

In the Southwick and DuValle neighborhoods however, CAC had a much different effect on the neighborhood women's grassroots activism. Through their already established alliances with WECC and others, as well as a large resident membership, CAC organizers provided SIC with an opportunity to expand upon their neighborhood improvement demands and reach for even more elaborate requests. With the help of activists-minded women such as Georgia Eugene and Benetha Ellis and Lula Hodges, all paid community organizers through CAC, Southwick and Cotter Homes residents began a larger project to establish new offices in the Park DuValle Neighborhood Service Center. This center already provided low-income community members with a few social service programs, but the expansion of the center was aimed at assisting with increasing rent payments, eliminating the lack of access to healthcare, and providing opportunities to attend job training programs. Speaking the new mission of the Center during the WOP, Lula Hodges, former Cotter Homes resident and DuValle Neighborhood Service Center board member, said "Jobs and health and housing was the main thing."156

In terms of her role with $\mathrm{CAC}$, Ellis described her involvement as directly targeted at organizing neighborhood women in the Southwick and Cotter Homes communities in the aforementioned service center. Ellis did not live in the housing community that which she was assigned, and in a 2006 interview, she identified a class

\footnotetext{
${ }^{156}$ Interview with Lula Hodges by David Cline, June 2, 2006, U-0114, in the Southern Oral History Program Collection \#4007, Southern Historical Collection, Wilson Library, University of North Carolina at Chapel Hill.
} 
conflict rooted between her and residents. ${ }^{157}$ Ellis reported that neighborhood women, at first, rejected her involvement with their neighborhood groups because she did not actually live in the Southwick or Cotter Homes public housing communities; instead, she lived in a single family home in the revitalized DuValle neighborhood. ${ }^{158}$ In the eyes of Southwick and Cotter Homes community members, women like Ellis probably could not fully understand their plight or the extent to which they had already been organizing for social change. Using Hunter as an example, Ellis said, "the residents on that [anti-poverty board] would not let anybody come down and dictate to them. And they were very aggressive. ${ }^{159}$ Residents in these communities had been working for years, at times unsuccessfully and with great frustration, to gain neighborhood improvements with the help of the WECC and other anti-poverty allies. For women like Hunter, embracing the methods and strategies of paid CAC organizers would be possible only after trust had time to grow between public housing residents and their assigned community organizer. This tension abated, however, and the cross-class neighborhood involvement between residents and organizers resulted in major expansions in the services offered to public housing community members in the Southwick and Cotter homes communities.

At meetings coordinated by CAC organizers, Southwick and DuValle community members gathered to discuss and plan action steps toward the expansion of the programs in the DuValle service center. Ellis described these meetings in an oral history interview decades later, in which she recalled Vernice Hunter as "volatile" and "aggressive."

\footnotetext{
${ }^{157}$ Interview with Benetha Ellis by David Cline, May 11, 2006 , U-0149, in the Southern Oral History Program Collection \#4007, Southern Historical Collection, Wilson Library, University of North Carolina at Chapel Hill.

${ }^{158}$ Ibid., 8.

159 Ibid., 6.
} 
According to Ellis, the group Hunter represented knew "they wanted to implement it in their own way, knowing what they really needed." 160 With the help of paid organizers, public housing residents utilized the meetings for potential collaboration to build upon their organizing strategies already in place. Though not without conflict, the added opportunity to exercise their grassroots activism did indeed benefit the total community through the establishment and growth of social service programs at the DuValle Neighborhood Service Center.

Similar to the initial conflict between the paid CAC organizers and public housing residents mentioned above, the SIC and Ruth Bryant also had a rocky relationship towards the end of their partnership. In her 1977 interview, Bryant did recount the federally mandated notion of maximum feasible participation as a beneficial component to housing activism in Louisville. She said that though WOP supported collective action between WECC and SIC members, the anti-poverty commission was restructured after 1965 and that "all this led up to people being involved and aware and wanting to articulate demands for better housing." 161 But Bryant also identified as a barrier particular city officials who rejected the cross-class coalition building promoted by the CAC and the anti-poverty programs. Due to her class status, Bryant attained a position on the Mayor's Advisory Committee and other community boards throughout the city. She found that some of the city officials on the anti-poverty boards, however, openly refused to include poor people in the decision making processes. Male anti-poverty board members such as Robinson (mentioned in Chapter One) and Robert Whiner were

\footnotetext{
${ }^{160}$ Ellis, B., (Oral History), 5.

161 Interview with Ruth Bryant, July 24, 1977, Oral History Center, University of Louisville Archives and Records Center, Louisville, Kentucky.
} 
"unbending men" according to Bryant, and blatantly refused to "sit on a committee with anyone who had committed a felony." Bryant strongly opposed this kind of prejudice, and she herself began to receive negative attention from other members of the Mayor's Council. Notwithstanding her good intentions, they came at a price to Bryant. While public housing residents eventually got more opportunities to participate in the decision making processes that affected their lives, in the process they identified Bryant as a power hungry activist focused on her own neighborhood issues, mainly integration and open housing laws. ${ }^{162}$ Bryant states in her 1977 oral history that the available funds through the MHC and CAC divided public housing residents against their middle-class allies through a manipulation of power structures and federal funds. ${ }^{163}$ From her perspective, the CAC and affiliated members were responsible for her dismissal and her ultimate choice to leave community work on the local level. Sadly, she reported that the CAC's involvement with grassroots community groups "really ran [her] out of that community." 164

Notwithstanding the divisions that occurred between public housing activists and middle-class black women, the effects of neighborhood organizing and the influence of the CAC cannot go unnoticed. Examined in Chapter Two, women were successful in many areas of neighborhood improvement pre-WOP. But as has been illustrated, the implementation of the WOP did, in fact, expand community action efforts of neighborhood women and created profound changes in Louisville's west end

\footnotetext{
162 Ibid., 29.

${ }^{163}$ Ibid.

${ }^{164}$ Ibid.
} 


\section{CONCLUSION}

"When women control their past they will control their future." Gerda Lerner

The story of the West End Community Council, the Southwick Improvement Club, and the Beecher Terrace Improvement club and their involvement with the WOP and the City-County Action Commission illustrates the impact neighborhood organizations can have when class barriers are overcome and collective community action persists. The WECC was organized prior to the WOP, but through professional and working-class black and white leadership, federally funded Community Action Agencies funneled money into the council to work with the Southwick Improvement Club and other neighborhood clubs in the anti-poverty movement. This study has shown that the collective action among poor and black community members can and sometimes will do the necessary work to change the status of a blighted community; especially when supported by the city officials and bureaucrats who design the social policies that influence public housing residents' lives.

Also organized pre-WOP, the Southwick Improvement Club expanded the club's

membership base and achieved multiple neighborhood improvements after the declaration of the War on Poverty and the disbursement of federal anti-poverty funds. 
The SIC was able to organize and lead a community-wide neighborhood clean-up and dramatically change urban renewal plans supported by some of the city's most powerful institutions. The SIC also birthed community leaders who dedicated their lives to the improvement of their community. The story of Vernice Hunter and her activism illustrates that grassroots community action can be a benefit to the total community and therefore should be considered by the government and social service providers. Her protest resulted in the installation of the stoplight that still remains and, consequently, forced city officials to take seriously the safety precautions needed to keep her community safe.

Directly organized and promoted by the local CAA, the Beecher Terrace Improvement Club's (BTIC) story is by far the most remarkable among the groups profiled here. Through the use of federal anti-poverty funds and the direction of paid community organizers, residents formed the BTIC and influenced the Municipal Housing Commission (MHC) to update public housing security and to create a safer environment for families living in those projects. Additionally, neighborhood councils, formed by the MHC in response to pressure from the public housing residents, worked with BTIC members and altered the culture of responsibility between landlords and Beecher Terrace community members. The WOP and those that supported its mission were effective in creating lasting community change in Louisville's public housing communities. 
As illustrated by Bryant's story and that of the initial class conflict between CAC

organizers and some public housing residents, WOP funding also at times interfered with longstanding cross-class alliances and created new divisions between community members that were once allies. WOP critics may use this notion to critique the model for maximum participation because of such conflicts. But those new conflicts pale alongside the overall upsurge in both mass action by public housing residents and the new concrete changes in their circumstances that they won as a result of their partnership with other fellow community members.

Half a century has passed since the Johnson administration declared War on Poverty, and this anniversary has given some contemporary conservative critics a flashpoint to try and prove that the liberalist intention to uplift the poor through antipoverty programs and maximum participation was a waste of time, money, and political resources. Former Republication vice presidential candidate Paul Ryan, for example, released a 204 page report on March 3, 2014 that criticized the anti-poverty initiatives put in place throughout Johnson's War on Poverty. ${ }^{165}$ He argues that the poverty rate has barely declined since the 1960's, and “that federal programs not only failing to address the problem. They are in some significant respects making it worse." ${ }^{166}$ His viewpoints undoubtedly exemplify many of the same conservative values that guided the Municipal Housing Commission's policies in Louisville during the 1960's. This research argues

\footnotetext{
165 House Budget Committee Majority Staff. The War on Poverty: 50 Years Later. http://budget.house.gov/waronpoverty/2014. 166 Ibid., 9.
} 
against Ryan and his followers and implicitly endorses "maximum feasible participation of the poor" by illustrating how poor women have utilized political partnerships and community action funds to create lasting social change in poor and urban communities.

Despite claims against the value of anti-poverty programs, models for achieving social change utilizing the WOP component of maximum feasible participation have remained active in the Park DuValle neighborhood and other public housing communities in Louisville. According to the Louisville Metro Housing Authority's website, the Cotter and Lang residents were invited in 1994 to sit on a development council and help shape the neighborhood design and social service development plan that was funded through the Hope IV grant in $1996 .{ }^{167}$ This resulted in yet another major expansion at the DuValle Service Center housing the Bridges of Hope social welfare offices. Moreover, grantfunded community organizations like the Center for Neighborhoods and their Making Connections Network employ the same basic skill set of an all-black board of Resident Organizing Coordinators to lead some 1,300 center members in missions to provide educational opportunities and build safer neighborhoods. ${ }^{168}$

But the unfortunate reality is that these kinds of community programs have been struggling to retain funding over the last few decades. And possibly in connection with this fact is the increase in poverty rates in Louisville, particularly in the west end of town

\footnotetext{
167 Louisville Metro Housing Authority. "Park DuValle Revitalization." Accessed April 6, 2014. http://www.Imha1.org/hope_vi/park_duvalle_revitalization.php.

168 Center For Neighborhoods. "Organizing." Accessed April 6, 2014. http://www.centerforneighborhoods.org/orgmakconnetwhaismakcon.htm.
} 
over the last ten years. ${ }^{169}$ The positive effects of community organizing and the necessity of an investment in anti-poverty programs are demonstrated in the success of neighborhood groups like the Southwick Improvement Club and the Beecher Terrace Improvement Club. Their mere existence and successes raise a question about any exclusively top-down way of thinking about social and political change. This lack of acknowledgment of the necessity and desirability of community action is just one of the many reasons why historiographical research on black women's neighborhood clubs is so needed at this time in history. Only by rewriting and publicizing the history of women's activism in $20^{\text {th }}$ century politics and social movements will these powerful political leaders ever be able to fully assess the necessity of anti-poverty programs and the value of black, poor, and female voices in the bureaucratic methods of decision making.

169 Holt, Devone. "Saturday Academy." University of Louisville. Accessed April 7, 2014. http://louisville.edu/saturdayacademy/west-louisville-working-group/files/DevoneHoltpresentation.pdf.; State and County QuickFacts. "Louisville/Jefferson County (balance) QuickFacts from the US Census Bureau." Accessed April 9, 2014. http://quickfacts.census.gov/qfd/states/21/2148006.html. 


\section{REFERENCES}

\section{Books, Articles, and other Secondary Materials}

Adams, Luther. Way Up North in Louisville African American Migration in the Urban South, 1930-1970. Chapel Hill: University of North Carolina Press, 2010.

Carroll, Tamar W. 2007. Grassroots Feminism: Direct Action Organizing and Coalition Building in New York City, 1955-1995. PhD. Diss., University of Michigan, 2678. http://search.Proquest.com/docview/304842328?accountid=14665,

Cho, Sumi, Kimberle Crenshaw, and Leslie McCall. "Toward a Field of Intersectionality Studies: Theory, Applications, and Praxis." Signs 38, no. 4 (2013): 785-810.

Collins, Patricia H. Black Feminist Thought Knowledge, Consciousness, and the Politics of Empowerment. New York: Routledge, 2000.

Collins, Patricia H. "Learning from the Outsider Within: The Sociological Significance of Black Feminist Thought." Social Problems 33, no. 6 (1986): 14-32.

Greene, Christina. Our Separate Ways: Women and the Black Freedom Movement in Durham, North Carolina. Chapel Hill: University of North Carolina Press, 2005.

House Budget Committee Majority Staff. The War on Poverty: 50 Years Later. http://budget.house.gov/waronpoverty/2014.

K'Meyer, Tracy Elaine. Civil Rights in the Gateway to the South Louisville, Kentucky, 1945-1980. Lexington: University Press of Kentucky, 2009,

K'Meyer, Tracy E. "The West End Community Council: Building Interracial Community in Louisville's West End." Ohio Valley History, no. 7, no. 3 (2007).

Lerner, Gerda. "Early Community Work of Black Club Women." The Journal of Negro History 59, no. 2 (1974): 158-167. 
Louisville Metro Human Relations Commission. Making Louisville Home For Us All: A 20-Year Action Plan For Fair Housing. Louisville, KY, 2013.

Matusow, Allen J. The Unraveling of America: A History of Liberalism in the 1960s. New York: Harper \& Row, 1984.,

Nadasen, Premilla. Rethinking the Welfare Rights Movement. New York: Routledge, 2012, 13

Orleck, Annelise, and Lisa Gayle Hazirjian. The War on Poverty A New Grassroots History, 1964-1980. Athens: University of Georgia Press, 2011.

Roberts, Dorothy E. Killing the Black Body: Race, Reproduction, and the Meaning of Liberty. New York: Pantheon Books, 1997.

Terborg-Penn, Rosalyn. "Teaching the History of Black Women: A Bibliographical Essay."Women's Studies Quarterly 9, no. 2 (1981): 16-17.

Quadagno, Jill S. The Color of Welfare: How Racism Undermined the War on Poverty. New York: Oxford University Press, 1994, 14.

Valk, Anne M. ""Mother Power": The Movement for Welfare Rights in Washington, D.C., 1966-1972." Journal of Women's History 11, no. 4 (2000).

Williams, Rhonda Y., The Politics of Public Housing Black Women's Struggles against Urban Inequality. New York: Oxford University Press, 2004.

\section{Interviews}

Jones, Louise., interview by Aletia M. Robey, January 12, 2014.

Powers, Glenda., interview by Aletia M. Robey, January 12, 2014.

\section{Newspapers and Other Primary Sources}

Committee On Human Rights, Report of the Mayor's Committee On Human Rights, 1961, Walls Papers: University of Louisville Archives.

Louisville Courier Journal

Louisville Defender

Louisville Times 
Oral History Collection, Ekstrom Library, University of Louisville, KY.

Bryant, Ruth B, July 24, 1977.

Walls A., Murray, July 27, 1977.

Southern Oral History Collection, Wilson Library, University of North Carolina,

\section{Chapel Hill}

Ellis, Benetha, May 11, 2006.

Eugene, Georgia, May 15, 2006.

Hodges, Lula, June 2, 2006. 


\title{
APPENDIX
}

\section{ACRONYNMS}

\author{
ADC-Aid to Dependent Children \\ BSC- Black Solidarity Committee \\ BTIC- Beecher Terrace Community Club \\ CAA- City-County Action Commission \\ CAC- Community Action Commission \\ CAP- Community Action Program \\ EOA- Equal Opportunity Act \\ HNIC- Harris Neighborhood Improvement Club \\ MFY-Mobilization for Youth \\ MHC- Municipal Housing Commission \\ NWRO- National Welfare Rights Organization \\ SIC- Southwick Improvement Club \\ WEAC- West End Action Committee \\ WECC- West End Community Council \\ WOP- War on Poverty
}




\title{
CURRICULUM VITAE
}

\author{
Aletia M. Robey, M.A. \\ 502-345-3053 \\ Aletia.Robey@gmail.com
}

\section{Education}

University of Louisville

2014

\section{Masters in Women's and Gender Studies}

Spalding University

2010

Bachelor of Arts in Psychology

Honors Magna Cum Laude

Spalding University

2010

Study Abroad Program, Ireland

Jefferson Community and Technical College

2007

Associates in Applied Science, Human Services

\section{Professional Profile}

- A commitment to community organizing, outreach, and community research

- $\quad$ Skilled in project management, establishing goals, and developing strategic plans to meet milestones

- In-depth knowledge of community non-profits and social service agencies

- $\quad$ Extensive knowledge of basic computer applications and social media communication

- $\quad$ An ability to work as a team and independently

- $\quad$ Excellent written and verbal communication skills 


\section{Experience}

Grant Funded Projects

Kentucky Foundation for Women

Art Activities Leader- Special Project
Louisville, KY

March 2012 to Present

- $\quad$ Foster an environment conducive for creative expression

- $\quad$ Design and implement arts curricula to strengthen protective factors for families connected to the formerly incarcerated

- Lead art activities engaging children and family in the LMDC visitors lobby and neighborhoods with high recidivism rates

- $\quad$ Participate in learning and leadership groups to advance the goals of KFW and the Special Project

- $\quad$ Conduct community research and identify potential partnerships

\section{One Million Bones}

State Coordinator
Kentucky

August 2012 to July 2013

- $\quad$ Designed and implemented community outreach and media strategies

- $\quad$ Developed partnerships with the Muhammad Ali Institute and ArtsReach to sustain visibility of the project

- $\quad$ Secured donations and funding sources to develop community events

- Mobilized schools, community centers, and local institutions to contribute to the project by hosting genocide awareness and community arts workshops

- $\quad$ Collaborated with educators and artists to develop and implement age appropriate curricula 


\section{Employment}

Specialized Alternative for Families and Youth

Placement Coordinator
Louisville, KY

August 2013 to Present

- $\quad$ Gather information supplied by referral agencies and review and assess initial intake information from a therapeutic perspective

- Coordinate placement of foster youth with appropriate foster homes

- $\quad$ Communicate with referral agencies, divisional staff, and foster parents on status of placements and therapeutic needs of foster youth

Case Manager, Positive Transitions Grant

January 2011 to July 2012

- $\quad$ Empowered families to self-sufficiency by providing resources and community opportunities though effective case management

- $\quad$ Assisted in creating and implementing individualized treatment plans

- $\quad$ Executed community research to identify and utilize community outreach services

- $\quad$ Responsible for training new employees on Federal tracking database

- $\quad$ Provided accurate and timely documentation

Realizations, LLC

Direct Support Professional
Louisville, KY

September 2008 to December 2011

- $\quad$ Provided direct support to persons with disabilities in their home and in the community

- $\quad$ Assisted with personal care through hygiene and daily life skills

- $\quad$ Aided customer in creating a socially valued lifestyle

Assists colleagues in attaining goals outlined by the customer 
Jefferson County Public Schools

Family Service Worker
Louisville, KY

February 2010 to June 2010

- $\quad$ Recruited income eligible children and visited parents in home to identify needs

- Demonstrated educational materials for parents to use in the home

- $\quad$ Made community agency contacts to enhance the lifestyle of the families

Substitute Teacher

April 2009 to February 2010

- $\quad$ Created and maintained a classroom environment conducive to learning and age appropriate

- Guided the learning process toward the achievement of curriculum goals

- Assisted in the administration of Board policies, administrative regulations, and school rules 